"This is the peer reviewed version of the following article: WHITLEY, R. J., MACINNIS-NG, C. M. O., HUTLEY, L. B., BERINGER, J., ZEPPEL, M., WILLIAMS, M., TAYLOR, D. and EAMUS, D. (2011), Is productivity of mesic savannas light limited or water limited? Results of a simulation study. Global Change Biology, 17: 3130-3149.

which has been published in final form at doi:10.1111/j.1365-2486.2011.02425.x This article may be used for non-commercial purposes in accordance with Wiley Terms and Conditions for Self-Archiving." 


\section{Is productivity of mesic savannas light limited or water limited? Results} of a simulation study

6 Rhys J. Whitley ${ }^{1}$, Catriona M.O. Macinnis- $\mathrm{Ng}^{1,2}$, Lindsay B. Hutley ${ }^{3}$, Jason Berringer ${ }^{4}$,

7 Melanie Zeppel ${ }^{1,5}$, Mathew Williams ${ }^{6}$, Daniel Taylor ${ }^{1}$, Derek Eamus ${ }^{1,7}$

$8{ }^{1}$ Plant Functional Biology and Climate Change Cluster, University of Technology Sydney,

9 Australia

$10 \quad{ }^{2}$ Current address: School of Environment, University of Auckland, New Zealand

$11{ }^{3}$ School of Science \& Primary Industries, Charles Darwin University, Australia

$12{ }^{4}$ School of Geography and Environmental Science, Monash University, Australia

$13 \quad{ }^{5}$ Current address: Department of Biological Sciences, Macquarie University, Australia

$14{ }^{6}$ School of Geosciences, University of Edinburgh, UK

16 Keywords: Savannas, GPP; evapotranspiration; SPA modelling

$17 \quad{ }^{7}$ Corresponding author: Derek.Eamus@uts.edu.au; tel +(61) 29514 4154; FAX +(61) 2

$18 \quad 95144079$

19

20 Running title: Savanna GPP and evapotranspiration 


\section{Abstract}

24 A soil-plant-atmosphere model was used to estimate gross primary productivity (GPP) and evapotranspiration (ET) of a tropical savanna in Australia. This paper describes model modifications required to simulate the substantial $\mathrm{C} 4$ grass understory together with $\mathrm{C} 3$ trees. The model was further improved to include a seasonal distribution of leaf area and foliar nitrogen through ten canopy layers. Model outputs were compared to a five year eddy covariance dataset. Adding the $\mathrm{C} 4$ photosynthesis component improved the model efficiency and root-mean-squared error (RMSE) for total ecosystem GPP by better emulating annual peaks and troughs in GPP across wet and dry seasons. The C4 photosynthesis component had minimal impact on modelled values of ET. Outputs of GPP from the modified model agreed well with measured values, explaining between $79-90 \%$ of the variance and having a low RMSE (0.003-0.281 $\left.\mathrm{g} \mathrm{C} \mathrm{m}^{-2} \mathrm{~d}^{-1}\right)$. Approximately $40 \%$ of total annual GPP was contributed by $\mathrm{C} 4$ grasses. Total (trees and grasses) wet season GPP was approximately $75-80 \%$ of total annual GPP. Light-use-efficiency (LUE) was largest for the wet season and smallest in the dry season and C4 LUE was larger than that of the trees. A sensitivity analysis of GPP revealed that daily GPP was most sensitive to changes in leaf area index (LAI) and foliar nitrogen $\left(\mathrm{N}_{\mathrm{f}}\right)$ and relatively insensitive to changes in maximum carboxylation rate $\left(\mathrm{V}_{\mathrm{cmax}}\right)$, maximum electron transport rate $\left(\mathbf{J}_{\max }\right)$ and minimum leaf water potential $\left(\psi_{\min }\right)$. The modified model was also able to represent daily and seasonal patterns in ET, (explaining 68$81 \%$ of variance) with a low RMSE $\left(0.038-0.19 \mathrm{~mm} \mathrm{~d}^{-1}\right)$. Current values of $\mathrm{N}_{\mathrm{f}}, \mathrm{LAI}$ and other parameters appear to be co-limiting for maximising GPP. By manipulating LAI and soil moisture content inputs, we show that modelled GPP is limited by light interception rather than water availability at this site. 


\section{Introduction}

48 Globally, savannas cover an area larger than that of wet tropical rainforest and contribute approximately $30 \%$ of the gross primary productivity of all terrestrial ecosystems (Kanniah et al. 2009). They are continentally and globally important to the $\mathrm{C}$ cycle, are major determinants of regional water budgets and have high conservation, social, cultural and economic value (Eamus and Prior, 2001). Savannas have a discontinuous tree canopy above a continuous herbaceous layer, predominantly comprised of $\mathrm{C} 4$ grasses.

Savannas cover approximately $25 \%$ of the Australian continent (Hutley et al. 2000) and consequently make a significant contribution to Australia's carbon budget. Savannas of northern Australia experience a monsoonal climate with a distinct wet season (accounting for approximately $95 \%$ of the rainfall) and a dry season when grasses are absent. Despite this, C4 grasses make a significant contribution to the annual carbon cycle of savannas and approximately three quarters of the annual carbon flux of north Australian savannas occurs during the wet season (Chen et al. 2003) when the grasses often account for more than half of the total leaf area index (Eamus et al. 2001, Hutley et al. 2005). Similarly, stable isotope analysis suggests that approximately $40 \%$ of the annual net primary productivity of a savanna

64 in Brazil may have originated from C4 grasses, even though the LAI of grasses was only 0.4 and 0.2 for the wet and dry seasons respectively (Miranda et al. 1997).

66

While there have been many studies using the eddy covariance method to quantify carbon and water fluxes at savanna sites (Hutley et al. 2000, Eamus et al. 2001, Hutley et al. 2005), 
there is no widely available detailed mechanistic model currently available to accurately describe diurnal, seasonal and annual variation in gross primary productivity of ecosystems comprised of mixed C3 (trees and shrubs) and C4 (grasses) species. Indeed there is an urgent need to examine the patterns and drivers of savanna productivity because such information is central to understanding and predicting the response of savannas to climate change; to improve land and water management practices; and to inform policy initiatives in relation to C sequestration, woody thickening (Kanniah et al. 2009; Macinnis-Ng et al. 2010) and fire management (Beringer et al. 2007). The soil-plant atmosphere (SPA) model of Williams et al. (1996) is one of the most widely and successfully applied land surface exchange models and has been tested and validated across a range of diverse ecosystems, including Arctic tundra (Williams et al. 2001), Brazilian tropical rainforests (Williams et al. 1998; Fisher et al. 2007) and a temperate Australian woodland (Zeppel et al. 2008). The SPA model is a mechanistic model that predicts, amongst other parameters, carbon and water fluxes, leaf water relations and changes in soil moisture. However, it has not been applied to savannas because the productivity sub-model uses only the C3-photosynthesis model of Farquhar et al. (1980) and therefore cannot account for the behaviour of the C4 grass layer. In this paper we describe the changes required to incorporate $\mathrm{C} 4$ metabolism into the SPA model. This modified SPA model allows us to quantify ecosystem dynamics and to investigate the physiological mechanisms underlying observed behaviour.

Seasonality is a significant factor influencing productivity and water use of tropical ecosystems. For instance, an increase in the soil-root hydraulic resistance during the dry season caused seasonal reductions in carbon and water fluxes in a Brazillian rain forest (Williams et al. 1998). Wet season productivity in savannas creates a carbon sink of between 
930.1 and $0.2 \mathrm{~mol} \mathrm{C} \mathrm{m}^{-2} \mathrm{day}^{-1}$, but photosynthetic activity declines during the dry season and

94 the ecosystem may become a net source of $\mathrm{C}$ at this time (Chen et al. 2003). Seasonality in productivity is often attributed to stomatal closure and leaf loss during the dry season (Eamus and Prior, 2001) but gas exchange is limited by reduced $g_{s}$ in the afternoon in both seasons at

97 the Howard Springs site used in this study (Eamus et al. 1999; 2000). Soil water content and 98 root access to moisture must be accurately modelled for successful prediction of annual C 99 fluxes and evapotranspiration because soil water availability and atmospheric water content 100 interact with $g_{s}$ (Thomas and Eamus 1999; Thomas et al. 2000; Ju et al. 2006). Coupling 101 between seasonal rainfall patterns (and therefore soil water content) and productivity has 102 been observed at the leaf (Eamus et al. 1999), canopy (Eamus et al. 2001) and ecosystem 103 scales (Chen et al. 2003; Eamus 2003). The test of the modified SPA model, therefore, will 104 be its ability to reflect observed trends in water and carbon flux across seasons. We chose to 105 model GPP and evapotranspiration because changes in these fluxes in a savanna are strongly affected by (a) seasonal changes in total site LAI arising (principally) from changes in the

107 grass understorey; (b) daily changes in soil and atmospheric water content; and (c) hourly 108 changes in ambient conditions. Consequently modelling these fluxes provides an assessment of the behaviour of the model across a wide temporal scale.

111 The aims of this study were to first, modify the SPA model to incorporate both C3 and C4 112 photosynthesis; second, validate the modified model with five years of ecosystem GPP and

113 ET field-data for a savanna site; third investigate intra- and inter-annual variation in GPP of a 114 savanna; fourth, evaluate the sensitivity of GPP to a number of abiotic and biotic factors, with 115 particular reference to the question: are the parameter values displayed by this vegetation optimised for maximising GPP; fifth, present an annual carbon and water budget for the 
117 savanna that is disaggregated amongst seasons and C3 and C4 vegetation; and sixth,

118 determine whether GPP is limited by water availability or energy capture at this site.

\section{Materials and methods}

121 Study site

122 Eddy covariance (EC) data spanning five years (2001-2005) were collected near Howard 123 Springs (131 ${ }^{\circ}$ 'E, $\left.12^{\circ} 30^{\prime} \mathrm{S}\right)$, approximately $35 \mathrm{~km}$ southeast of Darwin, Northern Territory,

124 Australia. A full description of the site, species and EC methodologies are contained in

125 Hutley et al. (2000) and Eamus et al. (2001). In summary, vegetation at the site is

126 representative of a mesic open forest savanna with an overstorey dominated by Eucalyptus

127 tetrodonta (F.Muell.) and E. miniata (Cunn. ex Schauer), forming a discontinuous canopy of

128 about $50 \%$ cover. These two species account for approximately $90 \%$ of the tree basal area of

$1298-10 \mathrm{~m}^{2} \mathrm{ha}^{-1}$. Overstorey LAI varies seasonally because of the presence of brevi- semi- and

130 fully deciduous species, while the dominant evergreen species maintain canopy fullness

131 throughout the dry season (Williams et al. 1996). The understorey includes semi-deciduous

132 and deciduous small trees and shrubs but is dominated by C4 grasses such as annual Sorghum

133 spp. and Sarga spp. and the perennial grass Heteropogon triticeus. Climate is characterised as

134 wet-dry-tropical with highly seasonal rainfall and distinct wet (November to April inclusive)

135 and dry (May to October inclusive) seasons. The wet season accounts for approximately $95 \%$

136 of the average annual rainfall of $1750 \mathrm{~mm}$. Mean daily maximum temperatures remain above

$13730^{\circ} \mathrm{C}$ throughout the year, irrespective of season. 
141 The eddy covariance technique (Baldocchi et al. 1988) was used to calculate flux variables at 14230 min time intervals. The instruments were mounted on a $23 \mathrm{~m}$ flux tower within a plot of 143 open-forest savanna approximately 340 ha in size. The slope was less than $1^{\circ}$ and the fetch 144 was homogenous in all directions $(>1 \mathrm{~km})$. Wind speed and direction was measured with a 3-

145 D sonic anemometer (Campbell Scientific Inc. model CSAT3, Logan Utah, USA) and $\mathrm{CO}_{2}$ 146 and $\mathrm{H}_{2} \mathrm{O}$ fluxes were measured at $10 \mathrm{~Hz}$ with an LI-7500 open-path $\mathrm{CO}_{2} / \mathrm{H}_{2} \mathrm{O}$ analyser (Licor

147 Inc., Lincoln NE, USA). $\mathrm{CO}_{2}$ fluxes were corrected for fluctuations in air density due to 148 sensible and latent heat fluxes (Webb et al. 1980). Half-hourly values of rainfall, air 149 temperature, relative humidity, and net radiation were measured at the same height as the flux 150 data. Soil moisture at $10 \mathrm{~cm}$ depth was measured on a daily time-step. Soil moisture at this 151 depth is strongly correlated with deeper soil moisture during the wet season and reflects the 152 decline in soil moisture as the dry season progresses. Soil moisture values are a strong determinant of canopy gas fluxes in savannas of the Northern Territory (Eamus and Prior 2001). Missing or invalid flux data were gap-filled using either linear interpolation (for gaps 155 shorter than $3 \mathrm{hrs}$ ), or an artificial neural network (ANN) (for extended gaps; Beringer et al. 156 2007).

157 Gross primary production (GPP) was calculated as the sum of net $\mathrm{CO}_{2}$ flux $\left(F_{c}\right)$ and ecosystem respiration $\left(R_{e}\right) . R_{e}$ was assumed to be equivalent to night-time $F_{c}$ under adequate wind speed conditions (where friction velocity values were greater than $0.15 \mathrm{~m} \mathrm{~s}^{-1}$ ). Values of

$160 F_{c}$ collected under low wind speed conditions were excluded to avoid underestimation of $R_{e}$

161 due to inadequate turbulent mixing (Baldocchi et al. 2000, Mäkelä et al. 2006, Beringer et al. 162 2007). Using the ANN, daytime values of $R_{e}$ were calculated from values of temperature and 163 soil moisture. 
165 The SPA model simulates canopy exchanges of carbon and water at 30 minute resolution for multiple (up to 10) foliage layers. Model inputs include meteorological data, biophysical

167 parameters for vegetation and soil characteristics, and are described in Table 1. The model 168 was used in the form as described by Zeppel et al. (2008), and further explanation on the sub169 routines of SPA may be found in Williams et al. (1996, 1998, 2001). Modifications have

170 been made to the calculation of assimilation to include a $\mathrm{C} 4$ photosynthesis model, to describe understorey grass layers. In previous SPA applications a single phenology has been applied to all canopy layers. In the present study, the seasonal dying and regeneration of understorey grasses and the largely evergreen overstory leaf area are dynamic and

174 independent, as is the allocation of foliar nitrogen to each canopy layer. Both of these 175 modifications to SPA are described below.

178 The simplified C4 photosynthesis model as described by Collatz et al. (1992) was used to

179 determine the $\mathrm{C} 4$ net assimilation rate $\left(A_{n}^{C 4}, \mu \mathrm{mol} \mathrm{m}{ }^{-2} \mathrm{~s}^{-1}\right)$. Gross photosynthesis is given as a

180 function of the incident quantum flux density and $\mathrm{CO}_{2}$ intercellular partial pressure, in the 181 form of two nested quadratic equations. The first quadratic equation describes the flux determined by Rubisco activity and $\mathrm{RuP}_{2}$ regeneration, and is given as:

$$
\theta_{c j} M^{2}-\left(V_{c \max }+\alpha_{r f} Q_{p}\right) M+V_{c \max } \alpha_{r f} Q_{p}=0
$$


186 fraction of absorbed photons used by the reaction process, $V_{\mathrm{cmax}}\left(\mu \mathrm{mol} \mathrm{m} \mathrm{m}^{-2} \mathrm{~s}^{-1}\right)$ is the

187 maximum $\mathrm{C} 4$ Rubisco carboxylation rate and $M\left(\mu \mathrm{mol} \mathrm{m} \mathrm{s}^{-2}\right)$ is the $\mathrm{CO}_{2}$ flux determined by

188 both Rubisco and light-limited photosynthetic capacities and $\mathrm{Q}_{\mathrm{p}}$ is incident quantum flux

189 density. Equation 1 is therefore solved for $M$ as follows:

$$
M=\frac{V_{c \max }+\alpha_{r f} Q_{p} \pm \sqrt{\left(V_{c \max }+\alpha_{r f} Q_{p}\right)^{2}-4 \theta_{c j} V_{c \max } \alpha_{r f} Q_{p}}}{2 \theta_{c j}}
$$

190

191 Overall net C4 assimilation rate is similarly determined through a quadratic expression,

192 which includes the Rubisco and light-limited capacities described above as well as the $\mathrm{CO}_{2}$

193 limited flux rate, and is expressed as:

$$
\beta A_{g}^{2}-\left(M+C_{i} k_{T}\right) A_{g}+M C_{i} k_{T}=0
$$

194

where $\beta$ is a parameter describing the co-limitation between light, Rubisco and $\mathrm{CO}_{2}$ limited flux, $C_{i}\left(\mu \mathrm{mol} \mathrm{mol}{ }^{-1}\right)$ is the intercellular $\mathrm{CO}_{2}$ concentration of the mesophyll cells, $k_{T}=k_{p}-L / C_{i}$

$197\left(\mathrm{~mol} \mathrm{~m}^{-2} \mathrm{~s}^{-1}\right)$ and describes the interactions of $k_{p}$, a first-order rate constant for PEP carboxylase with respect to the ratio between $C_{i}$ and $L$; the amount of $\mathrm{CO}_{2}$ leakage from the

199 bundle sheath to the intercellular air spaces of the mesophyll. $A_{g}$ is the gross $\mathrm{C} 4$

200 photosynthetic rate, and is found by solving Equation 3 for $A_{g}$, given as:

$$
A_{g}=\frac{M+C_{i} k_{T} \pm \sqrt{\left(M+C_{i} k_{T}\right)^{2}-4 \beta M C_{i} k_{T}}}{2 \beta}
$$

$$
A_{n}^{C 4}=A_{g}-R_{d}
$$


203 Additionally parameters $V_{c m a x}, k_{T}$ and $R_{d}$ are all affected by variation in leaf temperature, and 204 so $Q_{10}$ temperature functions were used to modify these values accordingly (Collatz et al. 205 1992).

\section{LAI and foliar nitrogen matrix}

208 The model contains 10 canopy layers. Given the significant contribution of the grass to total

209 LAI (slightly larger than that of the overstorey LAI during the wet season), we define five of

210 the layers as grass (C4) and five of the layers as shrubs and trees (C3). Each grass layer was

$2110.3 \mathrm{~m}$ deep (a total height of $1.5 \mathrm{~m}$ ) and the tree layers were each $2.5 \mathrm{~m}$ deep, taking the total

212 canopy height to $14 \mathrm{~m}$. Seasonal variations in leaf area of each canopy layer were

213 incorporated into the phenology input file of the model. LAI of the overstorey was measured

214 each month for a year using the Adelaide technique (O'Grady et al. 2000). Understorey LAI

215 was also measured monthly using a direct harvest method of $21 \times 1 \mathrm{~m}^{2}$ quadrats at three

216 locations at Howard Springs with all grasses and woody saplings sampled. Allometric

217 relationships were developed for each species of grass and woody sampling describing the

218 relationship between plant biomass and leaf area to derive LAI (Hutley and Williams, unpub.

219 data). The understorey leaf area values ranged from 1.1 to 0.05 during the wet and dry

220 seasons respectively and the overstorey values were between 1.2 and 0.6 (Fig. 1). Measured

221 ground data were compared to monthly MODIS LAI values for the whole canopy for each of

222 the sample years. There were some small differences between years in total (overstorey and

223 understorey) LAI detected in the remote sensing but preliminary analysis showed that the

224 small changes in LAI caused a less than $2 \%$ difference in annual carbon and water fluxes in

225 the model. For this reason, we used the same LAI matrix for each year and focused on

226 capturing the seasonal changes in the leaf phenology file, rather than the inter-annual 
changes. This approach allowed for a realistic distribution of leaf area between the $\mathrm{C} 4$ and $\mathrm{C} 3$ components of the canopy throughout the year.

The majority of the reduction in LAI occurred in the understorey, during the onset of the dry season (from March onwards). Before rains arrive, the overstorey begins flushing with new leaves in October and then the grasses return from November (Palmer et al. 2008). The overstorey layers reflect the seasonal patterns of the four phenological types described by Williams et al. (1997). We assigned an evergreen phenology to the top two canopy layers (9 to $11.5 \mathrm{~m}$ and 11.5 to $14 \mathrm{~m}$ canopy height) because the two dominant tree species are evergreen. Consequently the LAI of these layers remains reasonably constant throughout the year, while the bottom three canopy layers of the overstorey ( 1.5 to $4 \mathrm{~m}, 4$ to $6.5 \mathrm{~m}$ and 6.5 to $9 \mathrm{~m}$ ) incorporated components of the brevi-deciduous, semi-deciduous and fully deciduous species and the LAI values declined slightly during the dry season, as shown in Williams et al. (1997).

241 Foliar nitrogen concentrations were determined from the literature for similar sites and species. Myrtaceous species may typically have a leaf $\mathrm{N}$ concentration of $1.7 \mathrm{~g} \mathrm{~m}^{-2}$ leaf area

243 (Prior et al. 2004) and the C4 grass Sorgham bicolor typically may have a leaf N

244 concentration of $1.6 \mathrm{~g} \mathrm{~m}^{-2}$ leaf area (Ghannoum et al. 2005). Based on maximum LAI of 2.35 and assuming the overstorey and understorey values were 1.2 and 1.15 respectively, the maximum total foliar $\mathrm{N}$ concentration was $3.88 \mathrm{~g} \mathrm{~m}^{-2}$ ground area. The minimum total foliar

$247 \mathrm{~N}$ concentration in the dry season was approximately $0.7 \mathrm{~g} \mathrm{~m}^{-2}$ ground area. We incorporated 248 some seasonal reductions in foliar $\mathrm{N}$ on a leaf area basis consistent with Prior et al. (2004).

249 The foliar N matrix for the 10 canopy layers was based on the LAI matrix (Fig. 1b,c). 
252 For this study we also include several statistical tests in order to analyse the performance of the SPA model estimates against the measured EC data. In addition to using the coefficient of determination $\left(\mathrm{R}^{2}\right)$ and root-mean-square error (RMSE) we have also used model efficiency

255 (ME), given as:

$$
M E=1-\frac{\sum\left(y_{i}-\hat{y}_{i}\right)^{2}}{\sum\left(y_{i}-\bar{y}_{i}\right)^{2}}
$$

256

257 which estimates the proportion of variance of the EC data explained by the 1:1 line (Medlyn et al. 2005). The ME can range between $-\infty$ and 1 , where a $\mathrm{ME}=1$ corresponds to a 'perfect' match between modelled and measured data, $\mathrm{ME}=0$ indicates that the model predictions are as accurate as the mean of the measured data, and a $\mathrm{ME}<0$ dictates that the measured mean is a better predictor than the model.

\section{Results}

\section{Meteorology}

264 Darwin and its environs are characterised by a distinct bi-modal wet season. Ninety five percent of the annual rainfall occurs between the start of November and the end of March

266 (Fig. 2). However, there were significant rainfall events in July, 2001, May, 2004, and

267 October (2001, 2004 and 2005), as is commonly observed in long-term records. There was

268 also significant inter-annual variability in annual total rainfall for the years $2001-2005$, with 2692003 receiving the most $(2467 \mathrm{~mm})$ and 2005 receiving the least $(1219 \mathrm{~mm})$. The long-term average annual rainfall for the site is $1750 \mathrm{~mm}$. 
272 Maximum solar radiation levels showed little variation between the wet season (typically 900

$273-1100 \mathrm{~W} \mathrm{~m}^{-2}$ ) and dry season (typically about $800 \mathrm{~W} \mathrm{~m}^{-2}$ ), reflecting the high latitude of the

274 site and the absence of cloud during the dry season (Fig. 2). Mean daily vapour pressure

275 deficit peaked in the dry season and was typically between 3.0 and $4.5 \mathrm{kPa}$ at this time (Fig.

276 2). In the wet season, VPD was generally lower and was predominantly within the range $1-$

$277 \quad 2.5 \mathrm{kPa}$ in the absence of rain.

278

279

Seasonal and annual patterns in GPP and ET

280

281 Values of ecosystem GPP derived from eddy covariance measurements were largest in the

282 wet season, typically within the range $4.0-8.0 \mathrm{gC} \mathrm{m}^{-2} \mathrm{~d}^{-1}$ (Fig. 3). Only rarely did GPP

283 decline below $3.0 \mathrm{gC} \mathrm{m}^{-2} \mathrm{~d}^{-1}$ in the wet season. Day-to-day variation in GPP in the wet season

284 closely reflected patterns in rainfall and solar radiation. From approximately mid-March

285 through to September, ecosystem GPP declined approximately exponentially to a minimum

286 of $1-2.0 \mathrm{gC} \mathrm{m}^{-2} \mathrm{~d}^{-1}$. The start of the increase in GPP following the dry season minima

287 generally began between mid-October and the early November (Fig. 3).

288

289 The SPA model was able to replicate the seasonal trends in GPP (Fig. 3). Including C4

290 photosynthesis greatly improved SPA's ability to simulate wet season GPP (Fig. 3a-b). While

291 the model underestimated GPP for October to April each year when C3 photosynthesis was

292 used for all canopy layers (Fig. 3a), incorporating the C4 subroutine for the grass layers

293 improved congruity between EC and model values (Fig. 3b). This is supported by improved

294 ME and RMSE values for GPP outputs when the C4 subroutine was active (Table 2). As was

295 observed in EC derived estimates, maximum GPP occurred in the wet season and ranged 
296 between 4 and $8 \mathrm{gC} \mathrm{m}^{-2} \mathrm{~d}^{-1}$ whilst minimum values of calculated GPP occurred in September.

297 The SPA model estimated the minimum value of GPP to be approximately $2 \mathrm{gC} \mathrm{m}^{-2} \mathrm{~d}^{-1}$.

298

299 Across all five years of study, there was a significant positive relationship between modelled

300 and observed GPP (Fig. 4, Table 2). The $R^{2}$ for the regression ranged from 0.79 (2004) to

3010.90 (2002), whilst the model efficiency (ME) ranged from 0.44 (2004) to 0.80 (2002) (Table

302

2). For large values of GPP (> $\left.6 \mathrm{gC} \mathrm{m}^{-2} \mathrm{~d}^{-1}\right)$ modelled values of GPP were over-estimated by up to $17 \%$ of observed values. In contrast, for small values of GPP $\left(<3 \mathrm{gC} \mathrm{m}^{-2} \mathrm{~d}^{-1}\right)$ the model tended to underestimate the values derived from EC measurements by up to $20 \%$ (Fig.

4). When data for all years were pooled, the regression of SPA versus observed GPP yielded an $\mathrm{R}^{2}$ of 0.86 , a model efficiency of 0.70 and a slope of 0.83 (Fig. 4, Table 2).

Seasonal and annual patterns of evapotranspiration (ET) closely matched those observed in GPP (Fig. 3). However, the C4 subroutine made very little difference to congruity between EC and model values (Fig. 3c-d, Table 2). Maximum rates of ET were observed in the wet season and ranged from $3-7 \mathrm{~mm} \mathrm{~d}^{-1}$, followed by an approximately exponential decline to a dry season minima of 1- $2 \mathrm{~mm} \mathrm{~d}^{-1}$. SPA was able to replicate these patterns closely; the $R^{2}$ for the regression ranged from 0.67 (2005) to 0.81 (2002), whilst the model efficiency (ME) ranged from 0.44 (2005) to 0.65 (2002) (Fig. 4, Table 2). When all years were pooled the regression of SPA versus observed ET yielded an $R^{2}$ of 0.75 , a model efficiency of 0.53 and a

316 slope of 0.83 (Fig. 4, Table 2). 
323 To examine diel patterns of ET and GPP across the year, observed or modelled values of ET

324 and GPP were binned across all 5 years for each hourly value across each day of the month to

325 produce a composite 12 month plot (Fig. 5). Clearly apparent are the daily patterns in ET and

326 GPP, with peak values occurring around midday, and the seasonal decline in maximum values of ET and GPP as the dry season progresses from April through October. Similar patterns in hourly ET and GPP were observed for EC and modelled data with modelled values generally falling within the $95 \%$ confidence range of observed data.

Partitioning total ET and GPP into C3 and C4 components

Using SPA model outputs it was possible to partition landscape carbon and water fluxes between the C3 overstorey and C4 understorey components. During the wet season total GPP ranged between $2-8 \mathrm{gC} \mathrm{m}^{-2} \mathrm{~d}^{-1}$ and the $\mathrm{C} 3$ tree and $\mathrm{C} 4$ grass understorey each accounted for approximately $50 \%$ of the total flux (Fig 6; SPA simulation). In contrast, the rate of water use of the C4 understorey only accounted for approximately $23-35 \%$ of the total water flux in the wet season, which exhibited peak values of approximately $5-6 \mathrm{~mm} \mathrm{~d}^{-1}$. During the dry season, when the grasses were absent, all $\mathrm{C}$ and water fluxes were accounted for by the $\mathrm{C} 3$ component of the vegetation as there was no leaf area or biomass to support any fluxes from the $\mathrm{C} 4$ grasses (Fig 6). 
348 Annual total GPP and water use values were calculated for the EC data and the SPA outputs

349 for each year (Fig 7a, b). Total GPP for the EC observations and SPA outputs ranged from

3501409 to $1560 \mathrm{gC} \mathrm{m}^{-2} \mathrm{y}^{-1}$ and 1440 to $1501 \mathrm{gC} \mathrm{m}^{-2} \mathrm{y}^{-1}$ respectively across the 5 years (Fig. 7a).

351 Wet season GPP accounted for between 74 and $81 \%$ (EC data) or 80 to $83 \%$ (SPA outputs) of

352 the annual total. Total annual water use ranged from $1052 \mathrm{~mm}$ to $1213 \mathrm{~mm}$ (EC data) or 1181

$353 \mathrm{~mm}$ to $1352 \mathrm{~mm}$ (SPA output) (Fig. 7b). Wet season water use accounted for 73 to $80 \%$ (EC

354 data) or 71 to $76 \%$ (SPA) of the annual total.

356 It is not possible to partition the carbon and water fluxes between the $\mathrm{C} 3$ and $\mathrm{C} 4$ components of the vegetation using EC data. However, our modified SPA is able to generate outputs for the two vegetation types independently (Fig 7c, d). During the wet season, the proportion of the total GPP that was accounted for by the C3 component was about $43 \%$ across the five

360 years and about $18 \%$ of GPP was contributed by the overstorey in the dry season (Fig. 7c).

361 During the dry season, there was no active $\mathrm{C} 4$ vegetation present therefore the contribution of 362 C4 grasses to total annual GPP was approximately $38 \%$. Proportions of transpiration for wet season overstorey, wet season understorey and dry season over storey were 54, 17 and 29\% respectively (Fig. 7d). Therefore, $83 \%$ of total annual transpiration was used by overstorey trees but only $62 \%$ of total ecosystem GPP was accounted for by C3 trees (Fig. 7c, d).

The relative contribution of changes in soil moisture and LAI to patterns in ET and GPP

369 In order to assess the relative importance of seasonal changes in either LAI or soil moisture 370 content on carbon and water fluxes, two simulations were used. In the first, LAI was kept 
constant at the peak wet season value for the entire year and soil moisture fluctuations occurred as normal in this simulation. In the second, soil moisture content was kept high at wet season values for the entire year but LAI showed normal seasonal cycles.

When LAI was kept constant all year both GPP and ET remained high all year, showing no significant decline in the dry season, despite significant declines in the water content of the upper soil profile during the dry season (Fig 8a). In contrast, when soil moisture content was kept artificially high all year and LAI declined as normal in the dry season, the normal dry season declines in ET and GPP were observed (Fig 8b). There were only very small differences in the patterns of GPP and ET for the control simulation (normal pattern of seasonal change in LAI and soil moisture content) and this second simulation.

GPP and ET are sensitive to many biotic factors, including foliar $\mathrm{N}$ concentration, LAI and many others. Using SPA we doubled and halved the value of many factors and compared average daily GPP and ET for one representative year (2003; Fig. 9). Of all the factors examined, seven are presented here. Doubling the foliar $\mathrm{N}$ concentration of all layers resulted in a small increase (about 15\%) in GPP and this was apparent for only a small part of the year

391 (April to July). In contrast, halving the foliar N concentration caused a larger decline (10 - 25 \%) for most, but not all, of the year (Fig. 9b). A similar response of GPP was observed when

393 LAI was halved or doubled, although the magnitude of the decline when LAI was halved was

394 larger (up to $50 \%$ decline) than that when foliar $\mathrm{N}$ was reduced (Fig. 9c). When LAI and 395 foliar $\mathrm{N}$ were doubled or halved in tandem (Fig. 9a) GPP increased by between $30 \%$ and 

potential, $V_{c m a x}$ and $J_{\max }$ had a very small impact on GPP (Fig. 9d, e, f, g). Halving the value of these 4 parameter values had a much larger impact on GPP than doubling their values (Fig 9d, e, f, g). ET was less sensitive to variation in these factors than GPP (Fig. 9). Halving or doubling of foliar N and LAI had no impact on ET (Figs. 9b, a), although ET did decline or increase when foliar $\mathrm{N}$ and LAI values were altered in tandem (Fig. 9a). ET was sensitive to changes in $\mathrm{G}_{\text {plant }}$ and minimum leaf water potential (Fig. 9d, e) but insensitive to changes in $\mathrm{V}_{\mathrm{cmax}}$ and $\mathrm{J}_{\max }$ (Fig. 9f, g).

Micro-meteorological drivers of GPP and ET

A comparison of the responses of hourly assimilation $\left(A_{n}\right)$ and transpiration $\left(E_{t}\right)$ to solar radiation $\left(R_{s}\right)$, vapour pressure deficit (VPD), soil moisture content and LAI in 2003 is presented in Fig. 10. Data are separated by season and canopy layer for clear interpretation of the patterns. $A_{n}$ increased curvi-linearly with increasing $R_{s}$ but there was a significant decline in maximum values of $A_{n}$ in the dry season (Fig 10a, b). Maximum $E_{t}$ vales were similar for wet and dry seasons for C3 canopy layers (Fig. 10c, d). C3 and C4 responses of $A_{n}$ to $R_{s}$ were

415 similar in the wet season (Fig. 10a) while C4 canopy layers had a much lower rate of $E_{t}$

416 during the wet season compared to C3 canopy layers (Fig. 10c). Small increases in VPD from

417 very low levels of VPD resulted in increases in $A_{n}$ in the wet season but when VPD exceeded $4181-2 \mathrm{kPa}$, any further increase reduced $\mathrm{A}_{\mathrm{n}}$ in both $\mathrm{C} 3$ and $\mathrm{C} 4$ canopy layers (Fig. 10e). There 419 was very little response to VPD during the dry season (Fig. 10f). For C3 canopy layers, $\mathrm{E}_{\mathrm{t}}$ 420 increased as VPD increased up to about $1.5 \mathrm{kPa}$, then $\mathrm{E}_{\mathrm{t}}$ declined when VPD increased 
421 further during the wet season (Fig. 10g). The C3 layers had a higher $\mathrm{E}_{\mathrm{t}}$ peak than C4 layers

422 (Fig. 10g) and $\mathrm{E}_{\mathrm{t}}$ did not peak in the dry season until VPD reached about $2.5 \mathrm{kPa}$ (Fig. 10h).

423 Soil moisture content did not impact on $A_{n}$ nor $E_{t}$ for either canopy layer in either season

424 (Fig. 10i-1), however, as LAI increased during a season, $\mathrm{A}_{\mathrm{n}}$ and $\mathrm{E}_{\mathrm{t}}$ increased to a plateau (Fig.

425 10m-p) for C3 and C4 canopy layers.

426

427 We used to SPA outputs to estimate water-use-efficiency (WUE) and light-use-efficiency

428 (LUE) of the C3 overstorey and C4 understorey separately (Table 3). Water-use-efficiency

429 was always larger in the wet season than the dry season by between 18 and $64 \%$. The WUE

430 of the understorey was always larger than that of the overstorey, typically by a factor of $2.8-$

4313 times. Similarly whole-canopy LUE for the overstorey was always $10-26 \%$ larger in the

432 wet season than the dry season and whole-canopy LUE for the understorey was always

433 approximately 66\% larger than the LUE for the overstorey (Table 3).

434

435 Discussion

436 GPP and the modified SPA model

437 The initial aim of this work was to successfully incorporate provision for a $\mathrm{C} 4$ grass layer

438 within the SPA model, thereby allowing its application to savannas and other ecosystems

439 with a significant $\mathrm{C} 4$ component. Adding the C4 photosynthetic sub-model and LAI/foliar N

440 matrix allowed us to significantly improve wet- and dry-season estimates of GPP. Thus, the

441 slope of the regression of measured and modelled GPP without the C4 capability (excluding

$442 \mathrm{C} 4$ photosynthesis routine and LAI/foliar N matrix) was 1.31 and the model efficiency was

4430.29 (data not shown). In contrast, the slope of this regression when the model included the

444 C4 capability was 0.83 and model efficiency increased to 0.70 , indicating a significant 
improvement in model performance. The RMSE was also significantly improved when the

446 C4 capability was added (RMSE values 0.0057 and 1.185 with or without C4 and phenology

447 matrix included, respectively). This improvement was not only because of the incorporation

448 of the $\mathrm{C} 4$ photosynthetic pathway for the grass understorey but also because of the capture of

449 seasonal dynamics of LAI and foliar N, especially for grass layers. With only a C3

450 photosynthetic sub-model GPP was underestimated by $25-30 \%$ during the wet season (data 451 not shown).

452 Variation in the ability of SPA to accurately reflect intra-annual variation (Table 2) may

453 result from the application of a single common LAI and foliar $\mathrm{N}$ dynamic across all years,

454 rather than having an individual input of LAI and foliar $\mathrm{N}$ for each year but preliminary

455 analysis showed using remotely sensed LAI data specific for each year changed annual fluxes

456 by no more than $2 \%$. Despite use of a single dynamic for LAI and foliar $\mathrm{N}$ for all years, for

457 most of the range of GPP values (1.0 to $\left.7 \mathrm{gC} \mathrm{m}^{-2} \mathrm{~d}^{-1}\right)$ the difference between observed and

458 modelled was less than $10 \%$. Similarly good correlations between observed and modelled

459 hourly values of GPP were obtained in both the wet and dry seasons (Fig 5), further

460 indicating that at this shorter time-scale the SPA model was able to describe diurnal patterns

461 in GPP.

Primary drivers of seasonal changes in GPP

464 GPP of this savanna site was smallest at the end of the dry season and largest in the mid-and 465 late wet seasons. There are three principal causes of this variation. First, seasonality of 466 changes in LAI of the savanna (trees and grasses) was a principle cause of the decline in GPP 467 observed at the end of the wet season. The annual grasses lose $100 \%$ of leaf area by May of 468 each year and approximately $10 \%$ of the woody species present are also dry-season 
469 deciduous (Williams et al. 1997). A further $15 \%$ are dry season semi- or brevi-deciduous

470 (Williams et al. 1997). Second, the decline in soil moisture of the upper soil profile (upper 1

$471 \mathrm{~m})$ that occurs throughout the dry season is associated with a decline in stomatal conductance

472 and photosynthetic rate of the trees (Prior et al. 1997a; Eamus and Cole 1997). This response

473 is clearly evident in Figs 5 and 7 where peak rates of GPP were up to $60 \%$ smaller in the dry

474 season than the wet season. The third cause of the decline was the increase in vapour pressure

475 deficit that occurred in the dry season compared to the wet season (Fig. 2). A decline in

476 stomatal conductance and leaf-scale photosynthesis in response to seasonal increases in VPD

477 have been observed previously (Prior et al. 1997b) at this site. An influence of declining soil

478 moisture content and diurnal changes in VPD are also present in the wet season but the

479 magnitude of the impact tends to be smaller in the wet season than the dry season because of 480 the interactive effect of VPD with soil moisture (Thomas et al. 1999). Although some studies 481 have shown seasonal variations in GPP may be strongly temperature dependent (Mäkelä et 482 al. 2006), we found minimal impact of temperature variation on GPP because the range of 483 daytime temperature change was relatively small at this site.

Inter-annual variation of site GPP and contribution of C4 photosynthesis

486 The savanna at Howard Springs was a net sink for carbon annually across all five years.

487 Measured annual totals of GPP estimated from eddy covariance ranged from 1409 - $1558 \mathrm{gC}$

$488 \mathrm{~m}^{-2} \mathrm{yr}^{-1}$ (Fig. 7). The equivalent range from the SPA output was $1516-1618 \mathrm{gC} \mathrm{m}^{-2} \mathrm{yr}^{-1}$.

489 Such estimates compare well with remotely sensed estimates of GPP using MODIS GPP

490 products 4.5 and 4.8 which predicted annual GPP for the same years as the present study to

491 be in the range $1120-1780 \mathrm{gC} \mathrm{m}^{-2} \mathrm{yr}^{-1}$ (Kanniah et al. 2009). Even during the dry season the

492 savanna maintained a positive carbon balance through having access to deep soil water stores 
493 in the profile and regulating water-use through stomatal closure and adjustment of LAI

494 (Eamus et al. 2000; Eamus et al. 2001; Kelley et al. 2007). Total wet season productivity

495 contributed approximately $74-81 \%$ (EC and SPA data) of the total annual productivity

496 because of the large contribution of the C4 grass layer to total ecosystem LAI and the large

497 rates of photosynthesis of $\mathrm{C} 4$ grasses. C3 vegetation accounted for approximately $62 \%$ of the

498 total annual GPP, despite the C3 vegetation having a substantial LAI for the entire year

499 whilst the grasses were present for only 6 months of the year.

501 One hypothesis to explain inter-annual variation in GPP at this site is the large inter-annual

502 variation in rainfall, both in terms of the total rainfall and the temporal distribution of rainfall

503 across the year. However, no relationship was found between any measure of measured or

504 modelled GPP (for example wet season or annual GPP) and any measure of precipitation (for

505 example total precipitation, or wet or dry season length $(P>0.05))$. In contrast, Leuning et

506 al. (2005) and Pepper et al. (2008), found a positive relationship between rainfall and site

507 productivity. However, the mean annual rainfall described by Leuning et al. (2005) is

508 approximately one third ( $\sim 37 \%)$ of that at Howard Springs and in Budyko's terminology

509 (see Donohue et al. 2007 for discussion) would be considered to be a water limited site,

510 whilst the NT savannas of the present study are energy, and not water, limited (see discussion

511 below). For energy limited sites, small-to-moderate variations in total rainfall are unlikely to

512 have significant effects on GPP. Furthermore the error in values of GPP calculated from EC

513 data are also likely to be of the order $\pm 150 \mathrm{gC} \mathrm{m}^{-2} \mathrm{y}^{-1}$ (Hutley et al. 2000) which may account

514 for much of the observed inter-annual variation in GPP.

515 The estimate of annual C4 grass GPP was approximately 5.7 tonnes $\mathrm{C} \mathrm{ha}^{-1} \mathrm{y}^{-1}$ (Fig 7).

516 Assuming that half of GPP is lost as respiration (a commonly assumed ratio; Waring et al., 
517 1998; McMurtrie et al., 2008) and half is sequestered to below-ground biomass, and

518 assuming that half the dry weight of grass is $\mathrm{C}$, this equates to a total grass dry biomass of

5192.85 tonnes $\mathrm{ha}^{-1} \mathrm{y}^{-1}$ available for combustion in savanna fires. This compares well with the

520 range of fine fuel load (including fine woody debris) that accumulates at this site each year

$521\left(1.58-4.26 \mathrm{t}\right.$ dry mass $\mathrm{ha}^{-1} \mathrm{y}^{-1}$; Beringer et al. 2007).

522

523 Light- use-efficiency derived from SPA

524 Light-use-efficiency of the overstorey canopy was larger in the wet season than the dry 525 seasons for all years (Table 3) as has been observed in leaf-scale measurements in tropical woodlands previously (Fordyce et al. 1995; Eamus and Cole 1997) and in eddy covariance data (Hutley et al 2001). The three causes of this response are first, increased VPD in the dry season, which can both decrease stomatal conductance and hence $\mathrm{C}$ flux but also increase transpiration (Fordyce et al. 1995; Eamus and Cole 1997; O’Grady et al. 1999; Eamus et al. 1999); second, increased leaf temperature to supra-optimal values (Prior et al. 1997b); and third, a decline in soil moisture which causes decreased stomatal conductance. The (C4) understorey exhibited a much larger (by 66\%) LUE than the C3 overstorey, reflecting the

$533 \mathrm{CO}_{2}$ concentrating mechanism, high assimilation rate and lower stomatal conductance

534 typically seen in C4 plants compared to C3 plants (Collatz et al. 1992).

537 The strong positive correlation between measured and observed rates of daily ET for all years 538 (Fig 4, Table 2) indicates that the inclusion of the $\mathrm{C} 4$ photosynthetic sub-routine was able to capture water fluxes of the grass canopy as well as the $\mathrm{C}$ fluxes. Similarly the range in 
540 estimates of total annual ET from the SPA model $(1181-1352 \mathrm{~mm})$ was comparable to that 541 observed in the EC data (1052 - $1213 \mathrm{~mm}$ ). Wet season ET accounted for $71-80 \%$ (EC and

542 SPA data) of the annual total ET and the C3 component of the landscape generally accounted

543 for $76-78 \%$ of the wet season total ET. These relativities in GPP and ET for the C3 and C4

544 components of the landscape resulted in much larger water-use-efficiencies (WUE) for the

545 grasses (typically more than 3 times larger WUE for the grasses) than the trees (Table 3).

546 This reflects the smaller stomatal conductance and larger photosynthetic rates of $\mathrm{C} 4$ grasses

547 compared to $\mathrm{C} 3$ trees.

550 A sensitivity analysis on the model's vegetation parameters revealed that GPP was very

551 sensitive to changes in LAI and total foliar $\mathrm{N}\left(\mathrm{N}_{\mathrm{f}}\right)$. Increasing LAI alone, whilst keeping $\mathrm{N}_{\mathrm{f}}$

552 constant resulted in an asymptotic responses of GPP. As LAI increased and $\mathrm{N}_{\mathrm{f}}$ remained

553 constant, the concentration of $\mathrm{N}$ within each leaf declined (a fixed amount of $\mathrm{N}$ was being spread across an increasingly large leaf area). Consequently net assimilation became limited through limitation in the rate of RuBP carboxylation. Conversely, when $\mathrm{N}_{\mathrm{f}}$ was increased with a constant LAI, a similar asymptotic response of GPP was observed as the canopy

557 became saturated with $\mathrm{N}$ and light interception limited GPP. It is noteworthy that the plateau 558 in GPP occurred at the level of LAI and $\mathrm{N}_{\mathrm{f}}$ corresponding to $100 \%$ of the current value. This suggests that the canopy LAI and $\mathrm{N}_{\mathrm{f}}$ are currently co-limited and hence have reached optimality. Optimality is defined here as having arisen through evolution such that vegetation

561 displays parameter values that maximise the $\mathrm{C}$ gain for a given investment of resources (for 562 instance foliar N). This is similar to the definition used by Schymanski et al. (2007). The 563 maximal (wet season) LAI value found to be optimal in our approach was $2.2-2.5$ which 
agrees well with the value of 2.5 derived by Schymanski et al. $(2007,2008)$ using a formal

optimality model. The biophysical parameters $G_{\text {plant }}, \Psi_{\min }, V_{c \max }$ and $J_{\max }$, were also found to

566 have current values that appear to be optimal, whereby the maximum rate of GPP was

567 attained at values of these parameters that correspond to the observed (100\%) value for each

568 parameter. Thus, doubling the parameter value did not, in any instance, significantly increase

569 GPP whilst halving the parameter value caused a small decline in GPP.

570

Energy versus water limited savanna productivity

572 The GPP and ET of arid and semi-arid sites are clearly water limited, whilst those of mesic sites are energy limited. All catchments can be shown to be somewhere along a continuum between extremely water limited and extremely energy limited sites (Budyko 1974; Donohue et al. 2007). Budyko (1974) developed a framework for modelling ET based on the relationship of available water and energy, and constrained by the limits of these two variables. We have used this conceptual framework to ask: are these savannas energy or water limited? Given the annual high rainfall and the long dry season without rain, the answer is not intuitively obvious.

When the SPA model was run for one year with a fixed LAI all year (set to wet season values for both the $\mathrm{C} 3$ and $\mathrm{C} 4$ components) but with real-time observed variation in soil moisture and other meteorological drivers, daily values of GPP (and ET) remained high all year at

583 values closely matching observed wet season values of GPP (Fig 8). Thus dry season declines in GPP (and ET) were not observed. This is in marked contrast to the alternative scenario, where a fixed (high) soil moisture content was maintained all year and normal variations in

586 C3 and C4 LAI were imposed. When this occurred, daily rates of GPP and ET closely

587 matched the observed values throughout the year. We conclude that this savanna site is 
588 limited by the amount of solar radiation intercepted by the canopy. The site is not water

589 limited, despite the presence of a 6 month dry season every year. This is in contrast to the

590 generally accepted view that savanna function and productivity are limited by water

591 availability (Kanniah et al. 2009) but is consistent with other findings in this study. The lack

592 of a relationship between annual GPP and any measure of rainfall at this site described above

593 indicates the unlikelihood of water limitation. Furthermore, sensitivity analysis revealed that

594 minimum leaf water potential and whole plant hydraulic conductance (both determinants of

595 water availability in the plant) had to be reduced to unrealistically low values for there to be

596 any impact on GPP (Fig. 9) suggesting GPP is unresponsive to water availability. Finally,

597 seasonal responses of hourly leaf-scale carbon and water fluxes were unresponsive to soil

598 moisture but were bound by values of radiation, VPD and LAI (Fig. 10).

599 Model outputs unaffected by artificially wet soil and the lack of a relationship between GPP

600 and rainfall or soil moisture are supported by sapflow measurements of tree transpiration at

601 the same site. Rates of sap flux remained constant throughout the year, with no seasonal

602 decline during the dry season (Hutley et al. 2000). Furthermore, these trees did not suffer

603 significant water stress during the dry season as leaf water potentials remained high, despite 6

604 months without rain (Duff et al. 1997). The constant rate of transpiration and lack of extreme

605 water stress together with late dry season canopy flushing was attributed to deep tree roots

606 (estimated to be $>6 \mathrm{~m}$ by Cook et al. 1998) extracting water from the capillary fringe of the

607 water table as it declined during the dry season (Hutley et al. 2000). The interaction of the

608 depth of rooting of eucalypts and the large water storage capacity of the soil within the root

609 zone (Cook et al. 1998) provides a consistent water supply for trees when precipitation is

610 scarce. Finally, Cernusak et al (2011) conclude that leaf-scale photosynthesis of Eucalyptus

611 and Corymbia tree species in these north Australian savannas was not light saturated at full

612 sunlight, which strongly supports our conclusion that the system is light limited. 
613 It is noteworthy that the annual grasses at this site are genetically predestined to die each

614 year, irrespective of soil moisture content (ie the decline in grass LAI is not in response to

615 declining soil moisture content). It is further noteworthy that irrigation of this savanna into

616 the dry season had very little impact on the LAI of the overstorey (Myers et al. 1998).

617 However, exclusion of fires for several years causes an increase in tree LAI which results in

618 an increase in measured GPP due to increased light capture and hence enhanced C uptake

619 (Williams et al. 2004, Beringer et al. 2007). Therefore, hydrological (Cook et al. 1998) and

620 ecophysiological (Duff et al. 1997, Hutley et al. 2000, Beringer et al. 2007) data from the site

621 support the model finding that productivity of the vegetation is not limited by water

622 availability (as this is available in deep stores throughout the year). We conclude that the

623 alternative hypothesis, that LAI limits interception of light which limits the maximum GPP,

624 and that the largest driver of the change in savanna LAI is driven by seasonal change in C4

625 grass LAI, is supported by the analyses presented and the outputs of the modelling.

626

\section{Conclusions}

628

629 Modelling C4 photosynthesis is important if we wish to correctly estimate savanna gas

630 exchange. Furthermore, it is critical that seasonal variation in LAI and foliar N content of

631 savanna grasses also be included. The modified SPA model containing an accepted

632 representation of $\mathrm{C} 4$ metabolism was able to capture both wet and dry season fluxes of

633 carbon and water of a north Australian savanna. The understorey $\mathrm{C} 4$ grasses contributed

634 approximately $38 \%$ to total savanna GPP and total wet season GPP accounted for

635 approximately $80 \%$ of total annual GPP. Modelled values of GPP agreed well with the eddy-

636 covariance derived estimates of GPP, explaining between $80-87 \%$ of the variance and having

637 a low RMSE. Several canopy parameter values (including LAI, foliar N, and $\mathrm{G}_{\text {plant }}$ ) appeared 
638 to be co-limiting, such that large increases in allocation of resources to any one of these

639 attributes did not result in large increases in GPP. Counter-intuitively, we conclude that GPP

640 at this site is limited by light interception rather than water availability despite a long and

641 pronounced dry season each year.

642 
643

644

645

646

647

648

649

650

651

652

653

654

655

656

657

658

659

660

661

662

663

664

665

666

667

668

669

\section{References}

Baldocchi DD, Finnigan J, Wilson K, Paw UKT, Falge E (2000) On measuring net ecosystem carbon exchange over tall vegetation on complex terrain. Boundary-Layer Meteorology, 96, 257-291.

Baldocchi DD, Hicks BB, Meyers TP (1988) Measuring biosphere-atmosphere exchanges of biologically related gases with micrometeorological methods. Ecology, 69, 13311340.

Beringer J, Hutley LB, Tapper NJ Cernusak LA (2007) Savanna fires and their impact on net ecosystem productivity in North Australia. Global Change Biology, 13, 990-1004.

Budyko MI, (1974) Climate and Life, New York, Academic Press.

Cernusak LA, Hutley, LB, Beringer J, Holtum, JAM and Turner BL.(2011) Photosynthetic physiology of eucalypts along a sub-continental rainfall gradient in north Australia. Agricultural and Forest Meteorology (2011). Doi:10.1016/j.agformet.2011.01.006.

Chen X, Hutley LB, Eamus D (2003) Carbon balance of a tropical savanna of northern Australia. Oecologia, 137, 405-416.

Collatz JG, Ribas-Carbo M, Berry JA (1992) Coupled Photosynthesis-Stomatal Conductance Model for Leaves of $\mathrm{C}_{4}$ Plants. Australian Journal of Plant Physiology, 19, 519-538.

Cook PG, Hatton TJ, Pidsley D, Herczeg AL, Held A, O’Grady A, Eamus D (1998) Water balance of a tropical woodland ecosystem, northern Australia: a combination of micro-meteorological, soil physical and groundwater chemical approaches. Journal of Hydrology, 210, 161-177.

Donohue RJ, Roderick ML, McVicar TR (2007) On the importance of including vegetation dynamics in Budyko's hydrological model. Hydrology and Earth System Sciences, 11, 983-995.

Duff GA, Myers BA, Williams RJ, Eamus D, O’Grady A, Fordyce IR (1997) Seasonal patterns in soil moisture, vapour pressure deficit, tree canopy cover and pre-dawn 
water potential in a Northern Australian savanna. Australian Journal of Botany, 45,

671

672

673

674

675

676

677

678

679

680

681

682

683

684

685

686

687

688

689

690

691

692

693

694 211-224.

Eamus D (2003) How does ecosystem water balance affect net primary productivity of woody ecosystems? Functional Plant Biology, 30, 187-205.

Eamus D, Cole S (1997) Diurnal and seasonal comparisons of assimilation, phyllode conductance and water potential of three Acacia and one Eucalyptus species in the wet-dry tropics of Australia. Australian Journal of Botany, 45, 275-290.

Eamus D, Prior L (2001) Ecophysiology of trees of seasonally dry tropics: Comparisons among phenologies. Advances in Ecological Research, 32, 113-197.

Eamus D, Hutley LB O’Grady AP (2001) Daily and seasonal patterns of carbon and water fluxes above a north Australian savanna. Tree Physiology, 21, 977-988.

Eamus D, Myers B, Duff G, Williams D (1999) Seasonal changes in photosynthesis of eight savanna tree species. Tree Physiology, 19, 665-671.

Eamus D, O'Grady AP, Hutley L (2000) Dry season conditions determine wet season water use in the wet-dry tropical savannas of northern Australia. Tree Physiology, 20, 12191226.

Farquhar GD, von Caemmerer S, Berry JA (1980) A biochemical model of photosynthetic $\mathrm{CO}_{2}$ assimilation in leaves of $\mathrm{C}_{3}$ Species. Planta, 149, 78-90.

Fisher RA, Williams M, Lola da Costa A, Malhi Y, da Costa RF, Almeida S, Meir P (2007) The response of an Eastern Amazonian rain forest to drought stress: results and modelling analyses from a throughfall exclusion experiment. Global Change Biology, 13, 1-18.

Fordyce IC, Duff GA, Eamus D (1995). The ecophysiology of Allosyncarpia ternata in northern Australia: tree physiognomy, leaf characteristics and assimilation at contrasting sites. Australian Journal of Botany, 43, 367-377. 
695 Ghannoum O, Evans JR, Chow WS, Andrews TJ, Conroy JP, von Caemmerer S (2005) Faster rubisco is the key to superior nitrogen-use efficiency in NADP-malic enzyme relative to NAD-malic enzyme C-4 grasses. Plant Physiology, 137, 638-650.

698 Hutley LB, O'Grady AP, Eamus D (2000) Evapotranspiration from eucalypt open-forest savanna of northern Australia. Functional Ecology, 14, 183-194.

700 Hutley LB, Leuning R, Beringer J, Cleugh HA (2005) The utility of the eddy covariance techniques as a tool in carbon accounting: tropical savanna as a case study. Australian Journal of Botany, 53, 663-675.

Ju W, Chen JM, Black TA, Barr AG, Liu J, Chen B (2006) Modelling multi-year coupled carbon and water fluxes in a boreal aspen forest. Agricultural and Forest Meteorology, 140, 136-151.

Kanniah KD, Beringer J, Hutley LB, Tapper NJ, Zhu X (2009) Evaluation of collection 4 and 5 of the MODIS GPP product and algorithm improvement at a tropical savanna site in northern Australia. Remote Sensing of Environment, 113, 1808-1822.

Kelley G, O'Grady AP, Hutley LB, and Eamus D (2007) A comparison of tree water use in two contiguous vegetation communities of the seasonally dry tropics of Australia: the importance of site water budget to tree hydraulics. Australian Journal of Botany, $55,700-708$.

Leuning R, Cleugh HA, Zegelin SJ, Hughes D (2005) Carbon and water fluxes over a temperate Eucalyptus forest and a tropical wet/dry savanna in Australia: measurements and comparison with MODIS remote sensing estimates. Agricultural and Forest Meteorology, 129, 151-173. the impact of climate change on GPP of open woodlands and the potential for woody thickening. Ecohydrology, 2. In Press. DOI 10.1002/eco.138 
Mäkelä A, Kolari P, Karimäki J, Nikinmaa E, Perämäki M, Hari P (2006) Modelling five years of weather-driven variation of GPP in a boreal forest. Agricultural and Forest Meteorology, 139, 382-398.

McKenzie N, Jacquier D, Isbell R, Brown K (2004) Australian Soils and Landscapes. CSIRO Publishing. Melbourne. 416 pp.

McMurtrie RE, Norby RJ, Medlyn BE, Dewar RC, Pepper DA, Reich PB, Barton CVM. 2008. Why is plant-growth response to elevated $\mathrm{CO}_{2}$ amplified when water is limiting, but reduced when nitrogen is limiting? A growth-optimisation hypothesis. Functional Plant Biology, 35: 521-534.

Medlyn BE, Robinson A, Clement R, McMurtrie RE (2005) On the validation of models of forest $\mathrm{CO}_{2}$ exchange using eddy covariance data: some perils and pitfalls. Tree Physiology, 25, 839-857.

Miranda AC, Miranda HS, Lloyd J et al. (1997) Fluxes of carbon, water and energy over Brazilian cerrado: An analysis using eddy covariance and stable isotopes. Plant Cell and Environment, 20, 315-328.

Myers BA, Williams RJ, Fordyce I, Duff, GA, Eamus D (1998) Does irrigation affect leaf phenology in deciduous and evergreen trees of the savannas of northern Australia? Australian Journal of Ecology, 23, 329-339

O’Grady AP, Eamus D, Hutley LB (1999) Transpiration increases during the dry season: patterns of tree water use in eucalypt open-forests of northern Australia. Tree Physiology, 19, 591-598

O'Grady AP, Chen X, Eamus D, Hutley LB (2000) Composition, leaf area index and standing biomass of eucalypt open forests near Darwin in the Northern Territory, Australia. Australian Journal of Botany, 48, 629-638. 
744 Palmer A, Fuentes S, Taylor DT et al. (2008) The use of pre-dawn leaf water potential and MODIS LAI to explore seasonal trends in the phenology of Australian and southern African woodlands and savannas. Australian Journal of Botany, 56, 557-563.

Pepper DA, McMurtrie RE, Medlyn BE, Keith H, Eamus D (2008) Mechanisms linking plant productivity and water status for a temperate Eucalyptus forest flux site: analysis over wet and dry years with a simple model. Functional Plant Biology, 35, 493-508.

Prior L, Eamus D, Duff GA (1997a) Seasonal and diurnal patterns of carbon assimilation, stomatal conductance and leaf water potential in Eucalyptus tetrodonta saplings in a wet-dry savanna in northern Australia. Australian Journal of Botany, 45, 241 - 258.

Prior L, Eamus D, Duff GA (1997b) Seasonal trends in carbon assimilation, stomatal conductance, pre-dawn leaf water potential and growth of Terminalia ferdinandiana, a deciduous tree of northern Australia. Australian Journal of Botany, 45, 53-69.

Prior L, Bowman DMJS, Eamus D (2004) Seasonal differences in leaf attributes in Australian tropical tree species: family and habitat comparisons. Functional Ecology, 18, 707718.

Schymanski SJ, Roderick ML, Sivapalan M, Hutley LB, Beringer J (2007) A test of the optimality approach to modelling canopy properties and $\mathrm{CO}_{2}$ uptake by natural vegetation. Plant Cell and Environment, 30, 1586-1598.

Schymanski SJ, Sivapalan M, Roderick ML, Beringer J, Hutley LB (2008) An optimalitybased model of the coupled soil moisture and root dynamics. Hydrology and Earth System Sciences, 12, 913-932.

Thomas DS, Eamus D (1999) The influence of predawn leaf water potential on stem hydraulic conductivity and foliar $\mathrm{ABA}$ concentrations and on stomatal responses to atmospheric water content at constant Ci. Journal of Experimental Botany, 50, 243251. 
Thomas DS, Eamus D, Bell D (1999) Optimization theory of stomatal behaviour II. Stomatal responses of several tree species of north Australia to changes in light, soil and atmospheric water content and temperature. Journal of Experimental Botany, 50, 393400.

Thomas DS, Eamus D, Shanahan S (2000) Studies on the influence of season, drought and xylem ABA on stomatal responses to leaf-to-air vapour pressure difference of trees of the Australian wet-dry tropics. Australian Journal of Botany, 48, 143-153.

Waring RH, Landsberg JJ, Williams M. 1998. Net primary production of forests: a constant fraction of gross primary production? Tree Physiology 18: 129-134.

Webb EK, Pearman GI, Leuning R (1980) Correction of flux measurements for density effects due to heat and water vapour transfer. Quarterly Journal of the Royal Meteorological Society, 106, 85-100.

Williams M, Rastetter EB, Fernandes DN et al. (1996) Modelling the soil-plant-atmosphere continuum in a Quercus-Acer stand at Harvard Forest: the regulation of stomata conductance by light, nitrogen and soil/plant hydraulic properties. Plant, Cell and Environment, 19, 911-927.

Williams RJ, Myers BA, Muller WA, Duff GA, Eamus D (1997) Leaf phenology of woody species in a north Australian tropical savanna. Ecology 78, 2542-2558.

Williams M, Malhi Y, Nobre A, Rastetter E, Grace J, Pereira M (1998) Seasonal variation in net carbon exchange and evapotranspiration in a Brazilliam rain forest. Plant Cell and Environmnet, 21, 953-968.

Williams M, Rastetter EB, Shaver GR, Hobbie JE, Carpino E, Kwiatkowski BL (2001) Primary production of an arctic watershed: an uncertainty analsysis. Ecological Applications, 11, 1800-1816. 
793 Williams RJ, Hutley LB, Cook GD, Russell-Smith J, Edwards A, Chen XY (2004) Assessing the carbon sequestration potential of mesic savannas in the Northern Territory, Australia: approaches, uncertainties and potential impacts of fire. Functional Plant Biology, 31, 415-422.

797 Zeppel MJB, Macinnis-Ng CMO, Palmer A et al. (2008) An analysis of the sensitivity of sap 798 flux to soil and plant variables assessed for an Australian woodland using a soil-plant799 atmosphere model. Functional Plant Biology, 35, 509-520.

800

801 
Table 1. Values used in SPA for this study.

804

805 SPA model input values indicating the name, symbol, units, value used and whether the data

806 were measured or estimated for the study site.

807

\begin{tabular}{|c|c|c|c|c|}
\hline Parameter/Variable & Symbol & Units & Value & Source \\
\hline Ambient atmospheric $\mathrm{CO}_{2}$ concentration & $\mathrm{C}_{\mathrm{a}}$ & $\mathrm{mmol} \mathrm{mol}^{-1}$ & 374 & $\begin{array}{l}\text { Measured, this } \\
\text { study. }\end{array}$ \\
\hline Canopy layer capacitance & $\mathrm{C}_{\mathrm{n}}$ & & 5000 & $\begin{array}{l}\text { Williams et al. } \\
1996\end{array}$ \\
\hline Canopy hydraulic conductivity & $\mathrm{G}_{\text {plant }}$ & $\begin{array}{l}\mathrm{mmol} \mathrm{m}^{-1} \mathrm{~s}^{-1} \\
\mathrm{MPa}^{-1}\end{array}$ & 3.5 & Zeppel et al. 2008 \\
\hline Layer height of soil & $\mathrm{H}$ & $\mathrm{m}$ & $\begin{array}{l}0.2 \text { to } 1.6 \\
\mathrm{~m} \text { depth, } \\
\text { then } 1.6 \text { to } \\
6.4 \mathrm{~m}\end{array}$ & Site estimate \\
\hline Leaf Area Index & LAI & $\mathrm{m}^{-2} \mathrm{~m}^{2}$ & 0.6 to 2.35 & $\begin{array}{l}\text { MODIS LAI } \\
\text { product and } \\
\text { measured values }\end{array}$ \\
\hline Proportion of LAI in top layer & $\mathrm{L}_{\text {top }}$ & & 0.125 & $\begin{array}{l}\text { Estimated using } \\
\text { Weibull } \\
\text { cumulative } \\
\text { distribution } \\
\text { function }\end{array}$ \\
\hline Areal concentration of leaf $\mathrm{N}$ & $\mathrm{N}$ & $\begin{array}{l}\mathrm{g} \mathrm{m}^{-2} \\
\text { ground area }\end{array}$ & 3.84 & $\begin{array}{l}\text { Prior et al. } 2004 \\
\text { and Ghannoum et } \\
\text { al. } 2005\end{array}$ \\
\hline Proportion of total canopy $\mathrm{N}$ in top layer & $\mathrm{N}_{\text {top }}$ & & 0.125 & $\begin{array}{l}\text { Estimated, this } \\
\text { study }\end{array}$ \\
\hline Fine root radius & $\mathrm{r}_{\mathrm{r}}$ & M & 0.0001 & $\begin{array}{l}\text { Measured, this } \\
\text { study. }\end{array}$ \\
\hline Air temperature & $\mathrm{T}_{\mathrm{a}}$ & ${ }^{\circ} \mathrm{C}$ & Variable & $\begin{array}{l}\text { Measured, this } \\
\text { study. }\end{array}$ \\
\hline Leaf temperature & $\mathrm{T}_{\mathrm{i}}$ & ${ }^{\circ} \mathrm{C}$ & Variable & $\begin{array}{l}\text { Measured, this } \\
\text { study. }\end{array}$ \\
\hline C3 RuBP carboxylation capacity & $\mathrm{C} 3 \mathrm{~V}_{\mathrm{cmax}}$ & $\mu \mathrm{mol} \mathrm{m} \mathrm{s}^{-2}$ & 73.6 & Zeppel et al. 2008 \\
\hline C3 Maximum electron transport rate & $\mathrm{C} 3 \mathrm{~J}_{\max }$ & $\mu \mathrm{mol} \mathrm{m} \mathrm{s}^{-2}$ & 129.8 & Zeppel et al. 2008 \\
\hline C4 RuBP carboxylation capacity & $\mathrm{C} 3 \mathrm{~V}_{\mathrm{cmax}}$ & $\mu \mathrm{mol} \mathrm{m} \mathrm{s}^{-1}$ & 47.0 & $\begin{array}{l}\text { Ghannoum et al. } \\
2005\end{array}$ \\
\hline $\begin{array}{l}\text { Transition between light-limited and } \\
\text { RuBisCO limited } \mathrm{CO}_{2} \text { flux }\end{array}$ & $\theta_{\mathrm{cj}}$ & 0.83 & unitless & Collatz et al. 1992 \\
\hline Intrinsic quantum yield & $\alpha_{\mathrm{rf}}$ & 0.067 & $\mathrm{~mol} \mathrm{~mol}^{-1}$ & Collatz et al. 1992 \\
\hline $\begin{array}{l}\text { Co-limitation between light, RuBisCO } \\
\text { and } \mathrm{CO}_{2} \text { limited flux }\end{array}$ & $\beta$ & 0.93 & unitless & Collatz et al. 1992 \\
\hline First order rate constant & $\mathrm{k}_{\mathrm{T}}$ & 0.7 & $\mathrm{~mol} \mathrm{~m}^{-2} \mathrm{~s}^{-1}$ & Collatz et al. 1992 \\
\hline$\delta \mathrm{A} / \delta \mathrm{g}_{\mathrm{s}}$ threshold for stomatal opening & I & $\%$ & 1.0007 & $\begin{array}{l}\text { Williams et al. } \\
1996\end{array}$ \\
\hline
\end{tabular}


Minimum sustainable leaf water potential Soil water potential

$\%$ soil clay content in top $10 \mathrm{~cm}$

$\%$ soil sand content in top $10 \mathrm{~cm}$

Draincheck - field capacity as fraction of total porosity

Latitude

Dimension of leaves

Root resistivity

Root biomass

Rooting depth
$\Psi_{\text {lmin }} \quad \mathrm{MPa} \quad-2.5$

$\Psi_{\mathrm{s}} \quad \mathrm{MPa} \quad-0.5$

$\%$

$\%$

fraction

○

$\mathrm{m}^{2}$

MPa s g $\quad 100$ $\mathrm{mmol}^{-1}$

$\mathrm{g}$

$\mathrm{m}$
5.0

45.0

0.5

$12^{\circ} 29.712$

'S

0.08

1930

6.4
Kelley et al. 2007

Pre-dawn leaf water potential, this study McKenzie et al. 2004

McKenzie et al. 2004

Zeppel et al. 2008

Measured, this study.

Prior et al. 1997a. Estimated, this study.

Chen et al. 2003 Chen et al. 2003 808

809 
810 Table 2: Model performance for each year and the total dataset for gross primary productivity

811 and evapotranspiration reported as $\mathrm{R}^{2}$, model efficiency (ME), root-mean-square error

812 (RMSE), slope and y-intercept. Values of ME range from $-\infty$ to 1, where 1 represents a

813 perfect match between measured and modelled values. Units of RMSE are $\mathrm{g} \mathrm{C} \mathrm{m}^{-2} \mathrm{~d}^{-1}$ for

814 GPP and $\mathrm{mm} \mathrm{d}^{-1}$ for ET.

\begin{tabular}{|c|c|c|c|c|c|c|c|}
\hline $\begin{array}{c}\text { Simulation } \\
\text { Type }\end{array}$ & Year & Output & $\mathbf{R}^{2}$ & ME & RMSE & Slope & Intercept \\
\hline \multirow{12}{*}{ C3 only } & \multirow{2}{*}{2001} & $G P P$ & 0.86 & 0.62 & 0.5788 & 1.04 & 0.45556 \\
\hline & & $E T$ & 0.78 & 0.58 & 0.1843 & 0.9 & 0.15756 \\
\hline & \multirow[t]{2}{*}{2002} & $G P P$ & 0.88 & 0.58 & 0.7753 & 1.29 & -0.19748 \\
\hline & & $E T$ & 0.82 & 0.65 & 0.1437 & 0.86 & 0.36164 \\
\hline & \multirow[t]{2}{*}{2003} & $G P P$ & 0.88 & 0.71 & 0.3870 & 1.26 & -0.50405 \\
\hline & & $E T$ & 0.75 & 0.47 & 0.0604 & 0.72 & 1.00741 \\
\hline & \multirow[t]{2}{*}{2004} & $G P P$ & 0.79 & 0.43 & 0.6450 & 0.88 & 1.06609 \\
\hline & & $E T$ & 0.76 & 0.50 & 0.1212 & 0.73 & 1.10041 \\
\hline & \multirow[t]{2}{*}{2005} & $G P P$ & 0.88 & 0.54 & 0.8887 & 1.25 & 0.02909 \\
\hline & & $E T$ & 0.69 & 0.45 & 0.0221 & 0.81 & 0.65499 \\
\hline & \multirow[t]{2}{*}{ All } & $G P P$ & 0.85 & 0.59 & 0.6550 & 1.14 & 0.18159 \\
\hline & & $E T$ & 0.76 & 0.54 & 0.0336 & 0.81 & 0.64933 \\
\hline \multirow[t]{12}{*}{ Mixed C3/C4 } & \multirow[t]{2}{*}{2001} & $G P P$ & 0.87 & 0.67 & 0.0875 & 0.75 & 0.90186 \\
\hline & & $E T$ & 0.77 & 0.58 & 0.1205 & 0.93 & 0.13424 \\
\hline & \multirow[t]{2}{*}{2002} & $G P P$ & 0.90 & 0.80 & 0.1124 & 0.95 & 0.31099 \\
\hline & & $E T$ & 0.81 & 0.65 & 0.0656 & 0.89 & 0.32019 \\
\hline & \multirow[t]{2}{*}{2003} & $G P P$ & 0.88 & 0.74 & 0.2806 & 0.89 & 0.15795 \\
\hline & & $E T$ & 0.73 & 0.46 & 0.1309 & 0.74 & 0.99381 \\
\hline & \multirow[t]{2}{*}{2004} & $G P P$ & 0.79 & 0.44 & 0.0025 & 0.64 & 1.47203 \\
\hline & & $E T$ & 0.76 & 0.49 & 0.1929 & 0.76 & 1.06808 \\
\hline & \multirow[t]{2}{*}{2005} & $G P P$ & 0.87 & 0.73 & 0.2248 & 0.91 & 0.60362 \\
\hline & & $E T$ & 0.67 & 0.44 & 0.0500 & 0.83 & 0.63642 \\
\hline & \multirow[t]{2}{*}{ All } & $G P P$ & 0.86 & 0.70 & 0.0057 & 0.83 & 0.69562 \\
\hline & & $E T$ & 0.75 & 0.53 & 0.0376 & 0.83 & 0.62319 \\
\hline
\end{tabular}

816 
Table 3: $\quad$ Using SPA outputs, annual and seasonal water and C fluxes, water-use-efficiency and light-use-efficieny have been partitioned between the $\mathrm{C} 3$ overstorey and the $\mathrm{C} 4$ understorey. $\mathrm{ET}=$ Evapotranspiration (other water fluxes are transpiration rates only). Over $=$ Overstorey; Under = understorey. By definition, the grass understorey is absent in the dry season and hence doesn't have $\mathrm{C}$ and water flux values.

\begin{tabular}{|c|c|c|c|c|c|c|c|c|c|c|c|c|c|}
\hline & \multirow[b]{2}{*}{ Year } & \multicolumn{4}{|c|}{ Annual } & \multicolumn{4}{|c|}{ Wet Season } & \multicolumn{4}{|c|}{ Dry Season } \\
\hline & & ET & $\begin{array}{c}\text { Over }+ \\
\text { under }\end{array}$ & Over & Under & ET & $\begin{array}{c}\text { Over }+ \\
\text { under }\end{array}$ & Over & Under & ET & $\begin{array}{l}\text { Over + } \\
\text { under }\end{array}$ & Over & Under \\
\hline \multirow[t]{5}{*}{ Water Use (mm) } & 2001 & 1243 & 805 & 674 & 131 & 926 & 571 & 440 & 131 & 317 & 234 & 234 & 0 \\
\hline & 2002 & 1352 & 914 & 754 & 160 & 1021 & 670 & 510 & 160 & 331 & 244 & 244 & 0 \\
\hline & 2003 & 1181 & 803 & 673 & 130 & 850 & 555 & 425 & 130 & 331 & 248 & 248 & 0 \\
\hline & 2004 & 1320 & 867 & 727 & 140 & 941 & 591 & 451 & 140 & 378 & 276 & 276 & 0 \\
\hline & 2005 & 1307 & 881 & 733 & 148 & 968 & 634 & 486 & 148 & 339 & 247 & 247 & 0 \\
\hline \multirow[t]{5}{*}{ Carbon uptake $\left(\mathrm{gC} \mathrm{m}^{-2}\right)$} & 2001 & & 1440 & 869 & 567 & & 1186 & 635 & 567 & & 254 & 254 & 0 \\
\hline & 2002 & & 1465 & 902 & 571 & & 1204 & 641 & 571 & & 261 & 261 & 0 \\
\hline & 2003 & & 1501 & 942 & 573 & & 1202 & 643 & 573 & & 299 & 299 & 0 \\
\hline & 2004 & & 1498 & 943 & 564 & & 1202 & 650 & 564 & & 293 & 293 & 0 \\
\hline & 2005 & & 1475 & 909 & 575 & & 1214 & 648 & 575 & & 261 & 261 & 0 \\
\hline \multirow{5}{*}{$\begin{array}{l}\text { WUE }\left(\mathrm{mmol} \mathrm{CO}_{2} \mathrm{~mol}^{-1}\right. \\
\left.\mathrm{H}_{2} \mathrm{O}\right)\end{array}$} & 2001 & & 2.68 & 1.93 & 6.49 & & 3.12 & 2.15 & 6.49 & & 1.63 & 1.63 & 0 \\
\hline & 2002 & & 2.40 & 1.79 & 5.35 & & 2.70 & 1.89 & 5.35 & & 1.60 & 1.60 & 0 \\
\hline & 2003 & & 2.80 & 2.10 & 6.61 & & 3.25 & 2.97 & 6.61 & & 1.81 & 1.81 & 0 \\
\hline & 2004 & & 2.59 & 1.95 & 6.04 & & 3.05 & 2.16 & 6.04 & & 1.59 & 1.59 & 0 \\
\hline & 2005 & & 2.51 & 1.86 & 5.83 & & 2.87 & 2.00 & 5.83 & & 1.59 & 1.59 & 0 \\
\hline $\mathrm{LUE}\left(\mathrm{mol} \mathrm{CO} \mathrm{mol}^{-1}\right.$ & 2001 & & 0.2011 & 0.1640 & 0.3046 & & 0.2206 & 0.1807 & 0.3046 & & 0.1424 & 0.1424 & 0 \\
\hline
\end{tabular}


photon)

2002

2003

2004

2005 $\begin{array}{lll}0.2046 & 0.1703 & 0.3068\end{array}$

$\begin{array}{llll}0.2096 & 0.1778 & 0.3078\end{array}$

$\begin{array}{lll}0.2092 & 0.1780 & 0.3030\end{array}$

$\begin{array}{lll}0.2060 & 0.1716 & 0.3089\end{array}$ $\begin{array}{lll}0.2240 & 0.1824 & 0.3068\end{array}$

$\begin{array}{llll}0.2236 & 0.1830 & 0.3078\end{array}$

$\begin{array}{lll}0.2236 & 0.1850 & 0.3030\end{array}$

$\begin{array}{llll}0.2258 & 0.1844 & 0.3089\end{array}$
0.14630 .1463

0.16760 .1676

0.16420 .1642

0.14630 .1463

0




\section{Figure legends}

Figure 1: Seasonal patterns in (a) total leaf area index (LAI); (b) C3 (tree) and C4 (grass) LAI (the same pattern was applied to all years); and (c) the vertical distribution of LAI through the entire savanna canopy during February when LAI was at its peak. Data were derived from MODIS images and on-ground measurements to create smoothed representations of wet and dry season variation in leaf area index.

Figure 2: Meteorological data measured at the eddy-covariance tower at Howard Springs for all years. Values shown are (a) short-wave solar radiation and maximum daily vapour pressure deficit; (b) maximum and minimum air temperatures; (c) soil moisture content and rainfall (vertical bars).

Figure 3: Annual patterns in ecosystem GPP (top panels) and evapotranspiration and transpiration (bottom panels) for the years 2001-2005 for eddy covariance outputs $(\diamond)$ and SPA model outputs $(+$ ). The shaded sections represent the dry season each year. All EC data represent total landscape fluxes but SPA model outputs are either the original C3-only SPA formulation ((a) and (c)) or the modified model with both C3 (tree) and C4 (grass) photosynthetic pathways incorporated ((b) and (d)).

Figure 4: Comparisons of measured (eddy covariance) and modelled values of evapotranspiration (af) and gross primary productivity (GPP, g-1). Each point represents a daily measurement each year or all years combined. Linear regressions and the 1:1 line are displayed in each plot. See Table 2 for $\mathrm{R}^{2}$ values for each plot.

Figure 5: Hourly patterns in (a) evapotranspiration (ET) and (b) gross primary productivity (GPP) for binned values of the year 2003. For each month, hourly values across each day were binned to demonstrate seasonal changes in diel patterns. Eddy covariance data are represented by circles and SPA model outputs are shown in as a solid black line. The grey shading represents the $95 \%$ confidence range of values measured with eddy covariance. 
Figure 6: Modelled daily values of (a) gross primary productivity and (b) transpiration for the C3 (tree) canopy (o), and C4 understorey (x) from 2001 to 2005. The shaded region represents the dry season of each year.

Figure 7: Seasonal (wet and dry season) values of (a) gross primary productivity and (b) evapotranspiration for years 2001 to 2005 for eddy covariance and SPA model outputs. Model outputs of GPP and transpiration are also disaggregated into C3 (overstorey) and C4 (understorey) components for wet and dry seasons in (c) and (d).

Figure 8: A comparison of model outputs of GPP and transpiration for two contrasting scenarios. In the first scenario, (a) leaf area index (LAI) was kept constant all year and soil water content (SWC) varied seasonally according to observed values in a single (2003) year. In the second scenario (b) soil moisture was kept high throughout the year and LAI showed the standard seasonal decline in the dry season. The grey shading represents the dry season. In both scenarios, model outputs were compared with the output from the "normal simulation" where both LAI and soil moisture content varied seasonally.

Figure 9: Sensitivity analysis demonstrating the consequence of varying (a) foliar $\mathrm{N}$ and leaf area index (LAI) simultaneously; (b) foliar N or (c) LAI separately; (d) whole plant hydraulic conductance $\left(\mathrm{G}_{\text {plant }}\right)$, (e) minimum leaf water potential $\left(\psi_{\min }\right)$, (f) maximum carboxylation rate $\left(\mathrm{V}_{\mathrm{cmax}}\right)$ and $(\mathrm{g})$ maximum electron transport rate $\left(\mathrm{J}_{\max }\right)$ on daily gross primary productivity $(\mathrm{GPP})$ and evapotranspiration (ET). Values for each parameter were reduced or increased relative to the standard control simulation, defined as $100 \%$ (see Table 1 for actual parameter values used in control simulations).

Figure 10: Seasonal responses of hourly values of assimilation $\left(A_{n}\right)$ and transpiration $\left(E_{t}\right)$ to solar radiation (a-d), vapour pressure deficit (e-h), soil moisture content (i-l) and LAI (m-p) for the wet 
and dry seasons of 2003. Data were separated into C3 (o) and C4 (x) components of the vegetation. Lines shown are the 95\% confidence boundaries for C3 (dashed) and C4 (solid) canopy layers.

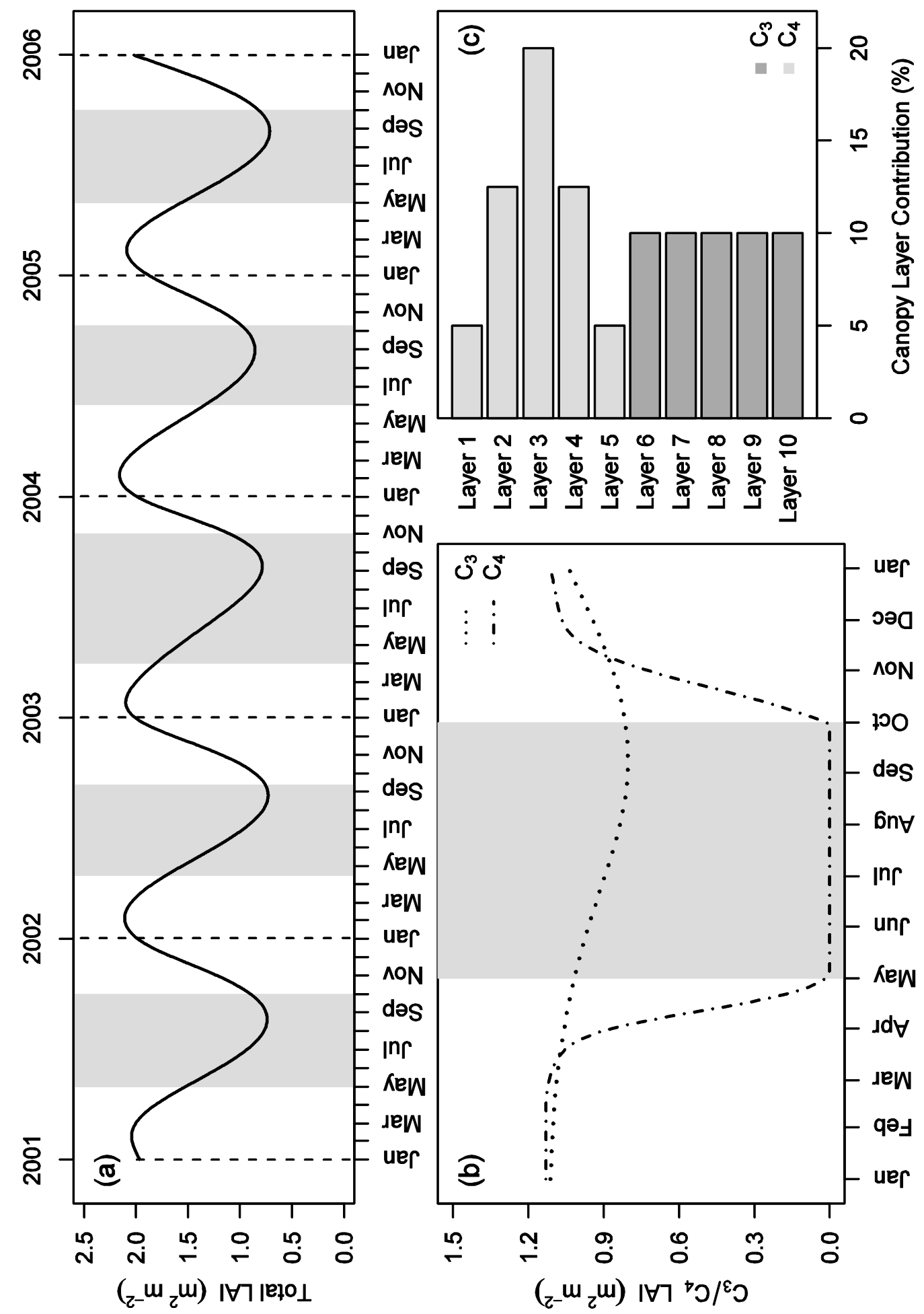


(edy) ad^ unu!xew

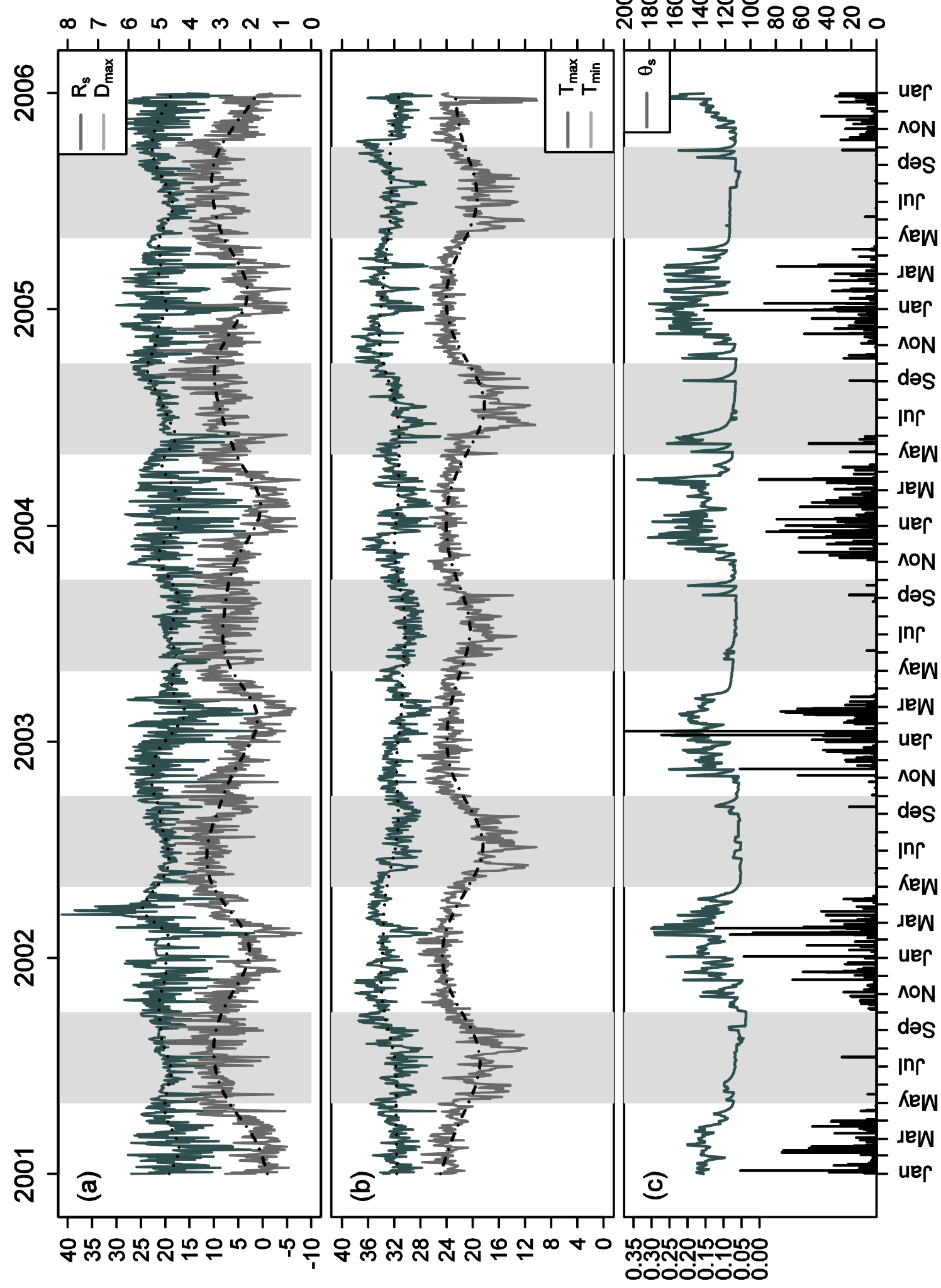
(__p ${ }_{2-}$ w rW) uo!̣e!pey dejos

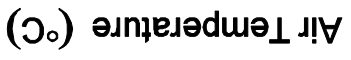

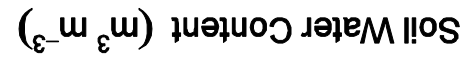




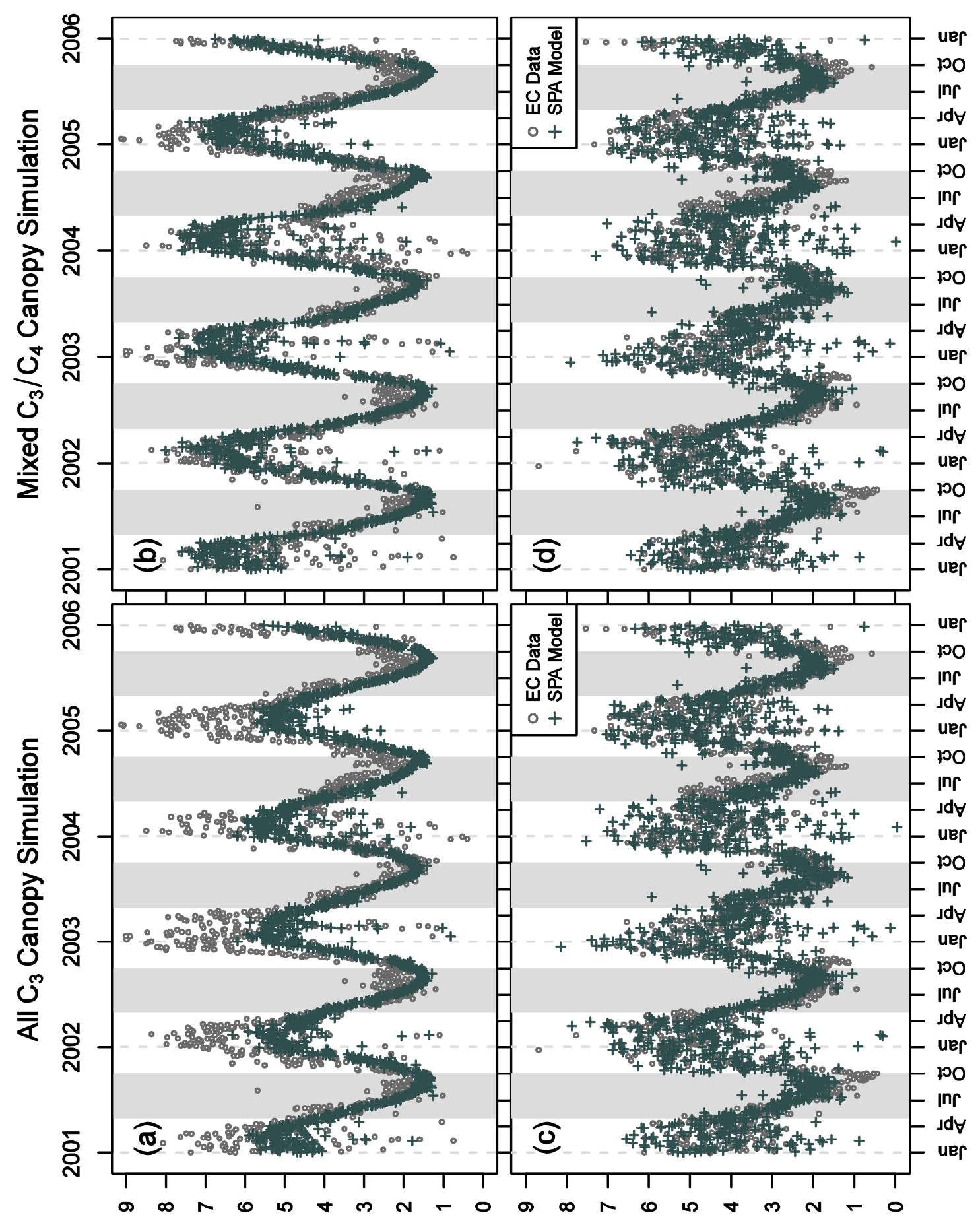

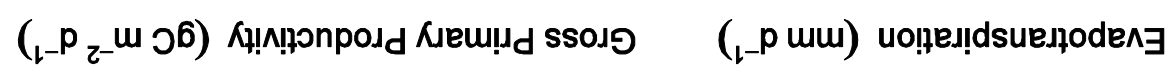




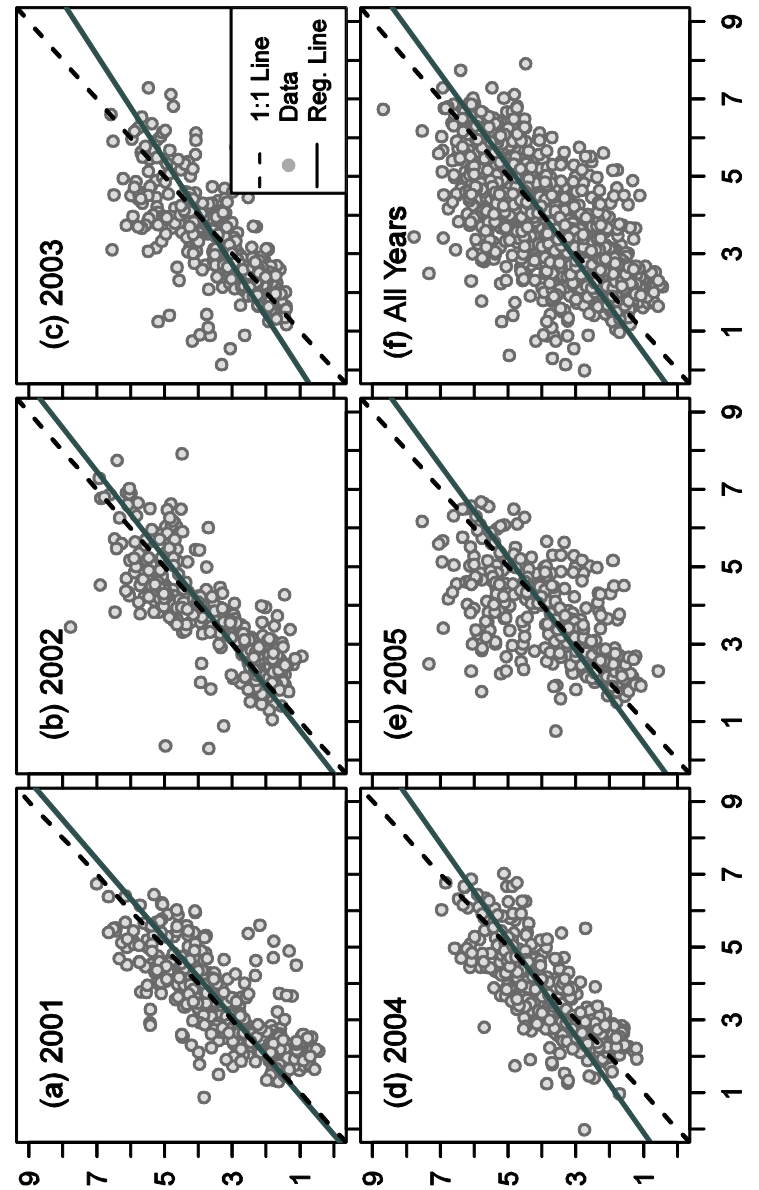

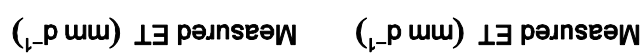

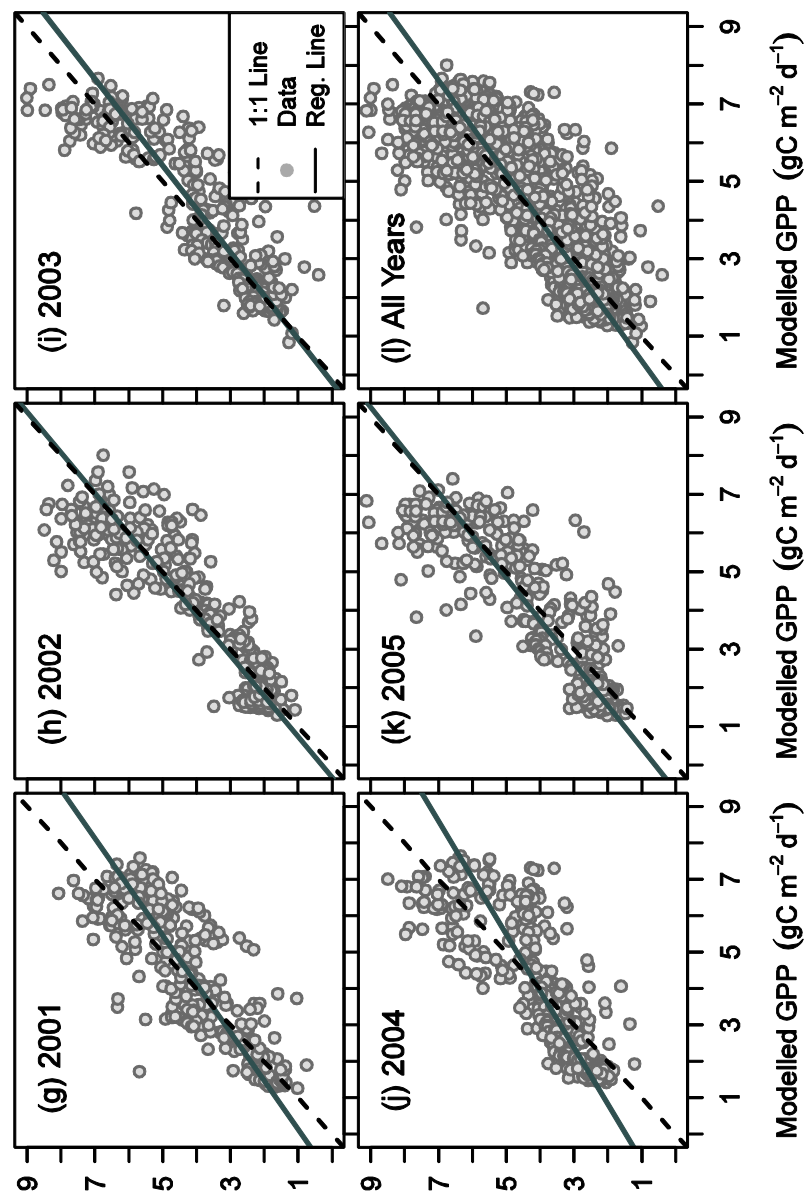

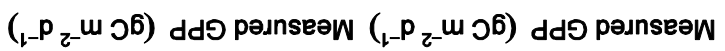




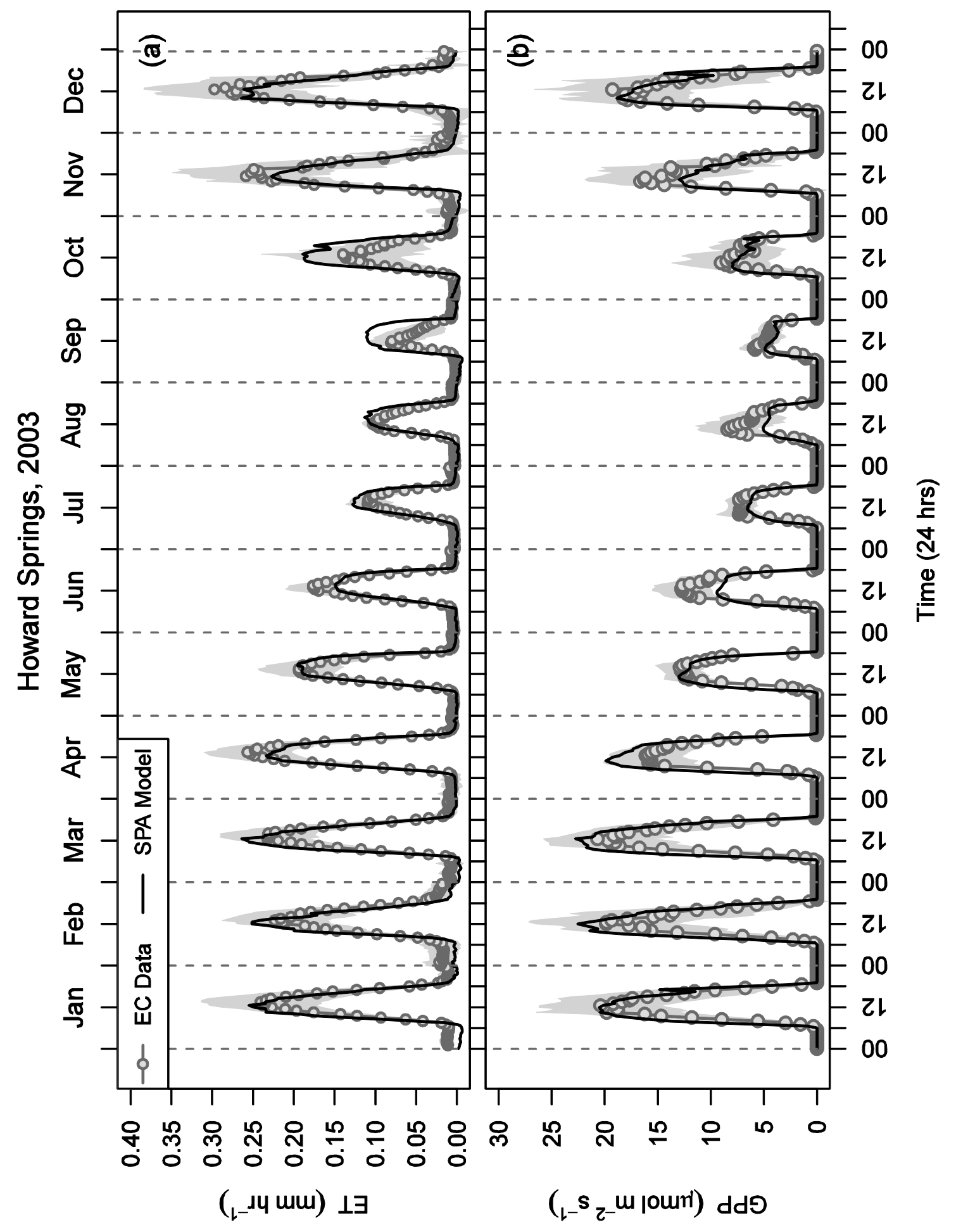




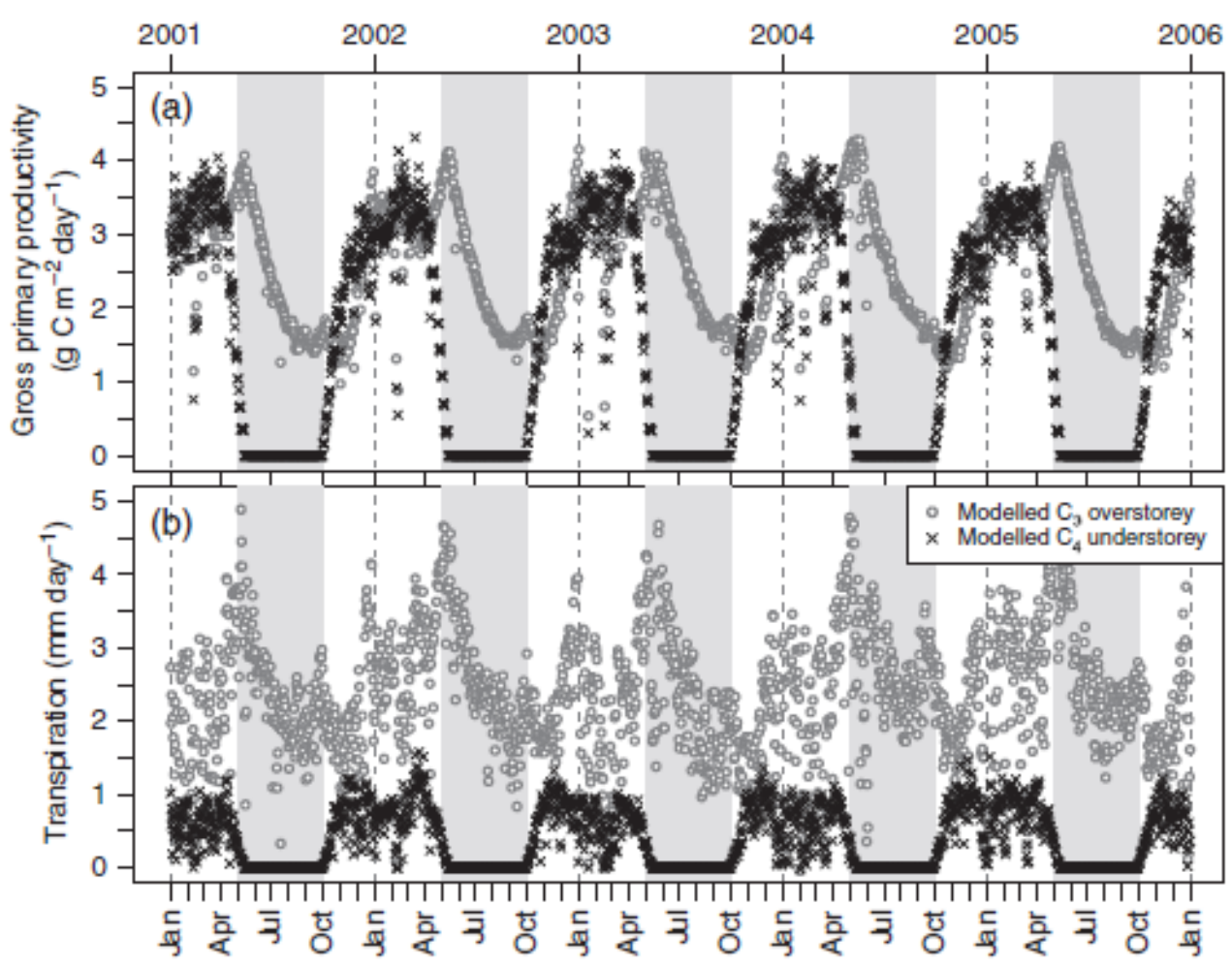




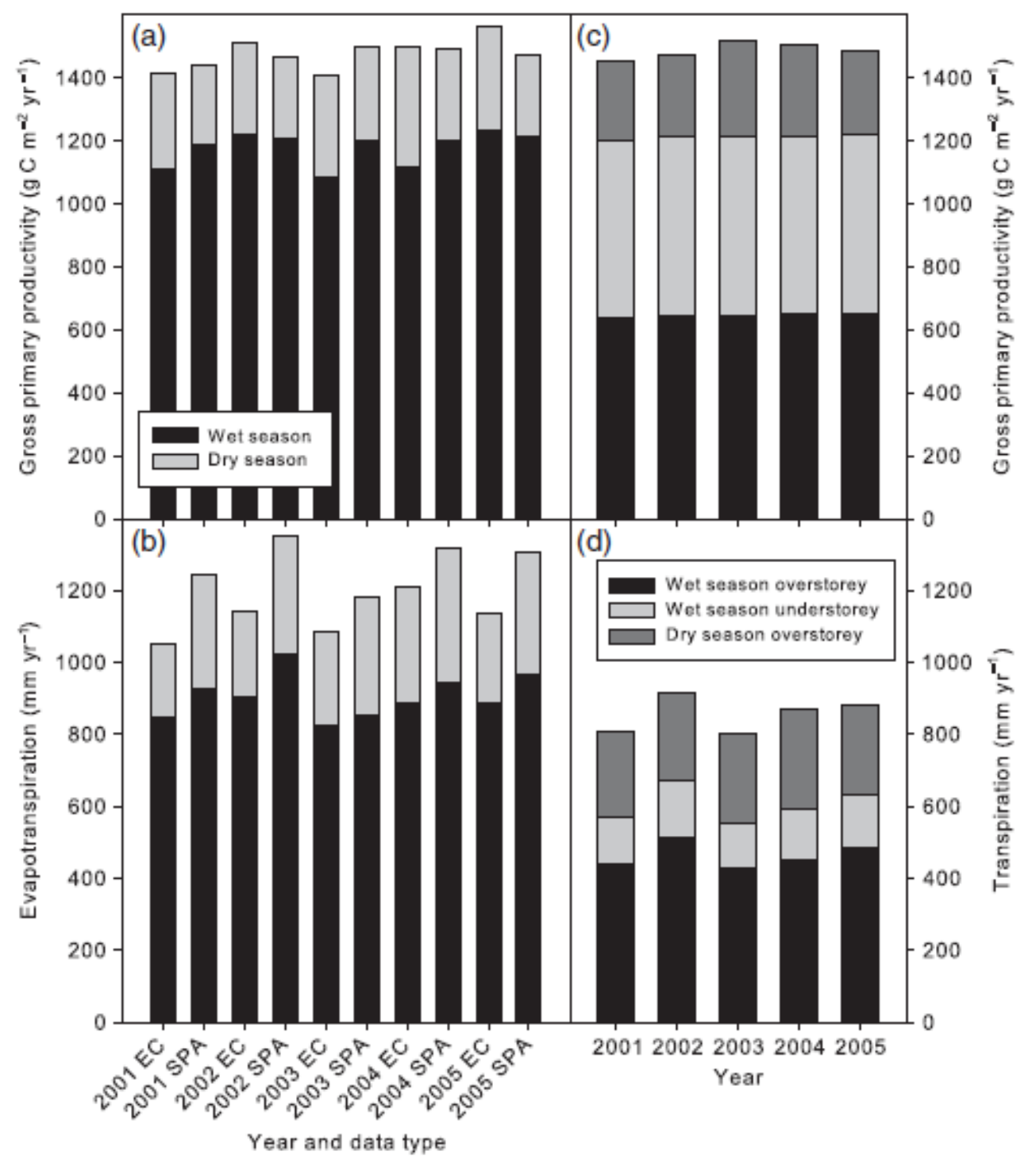




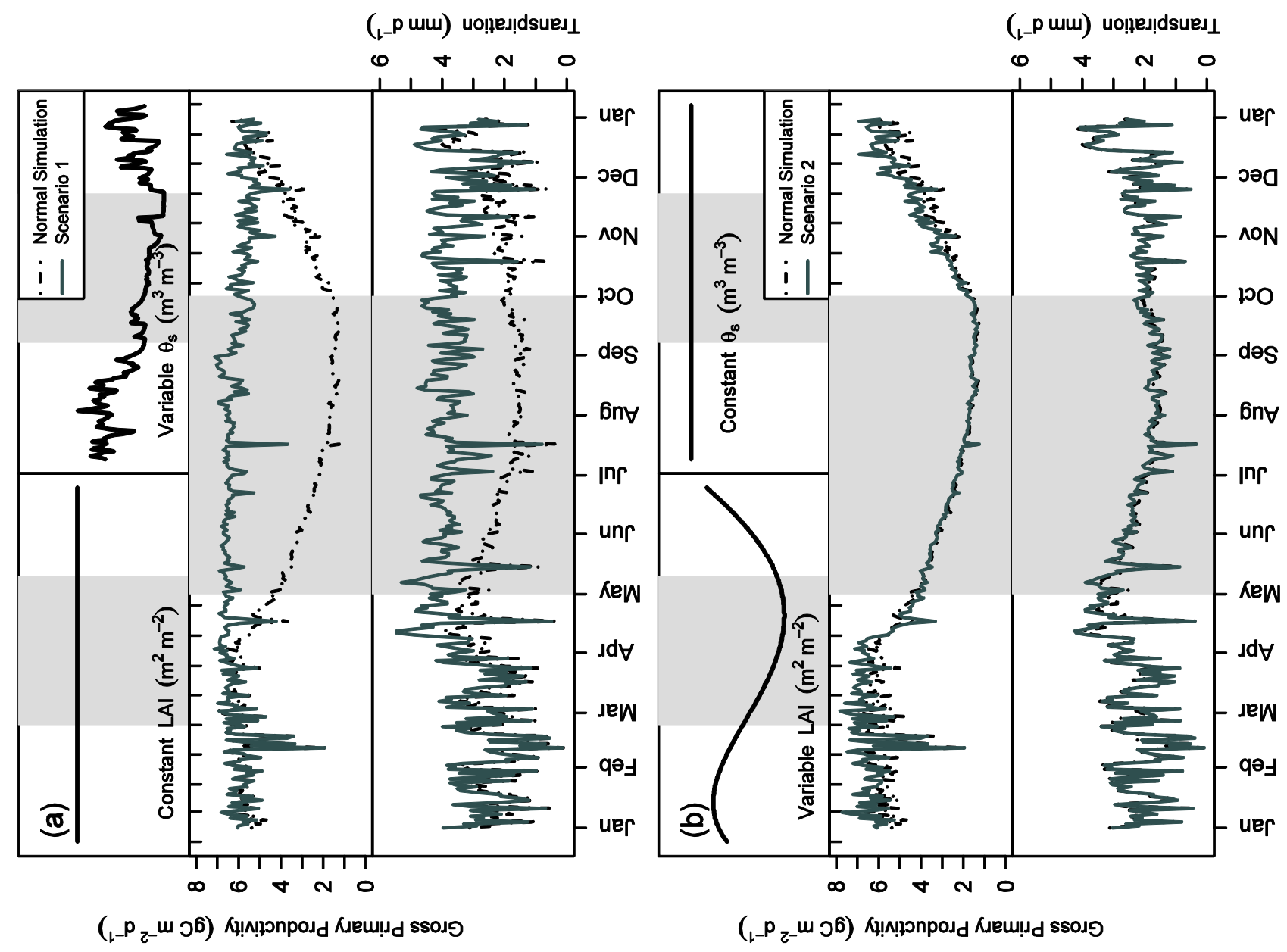




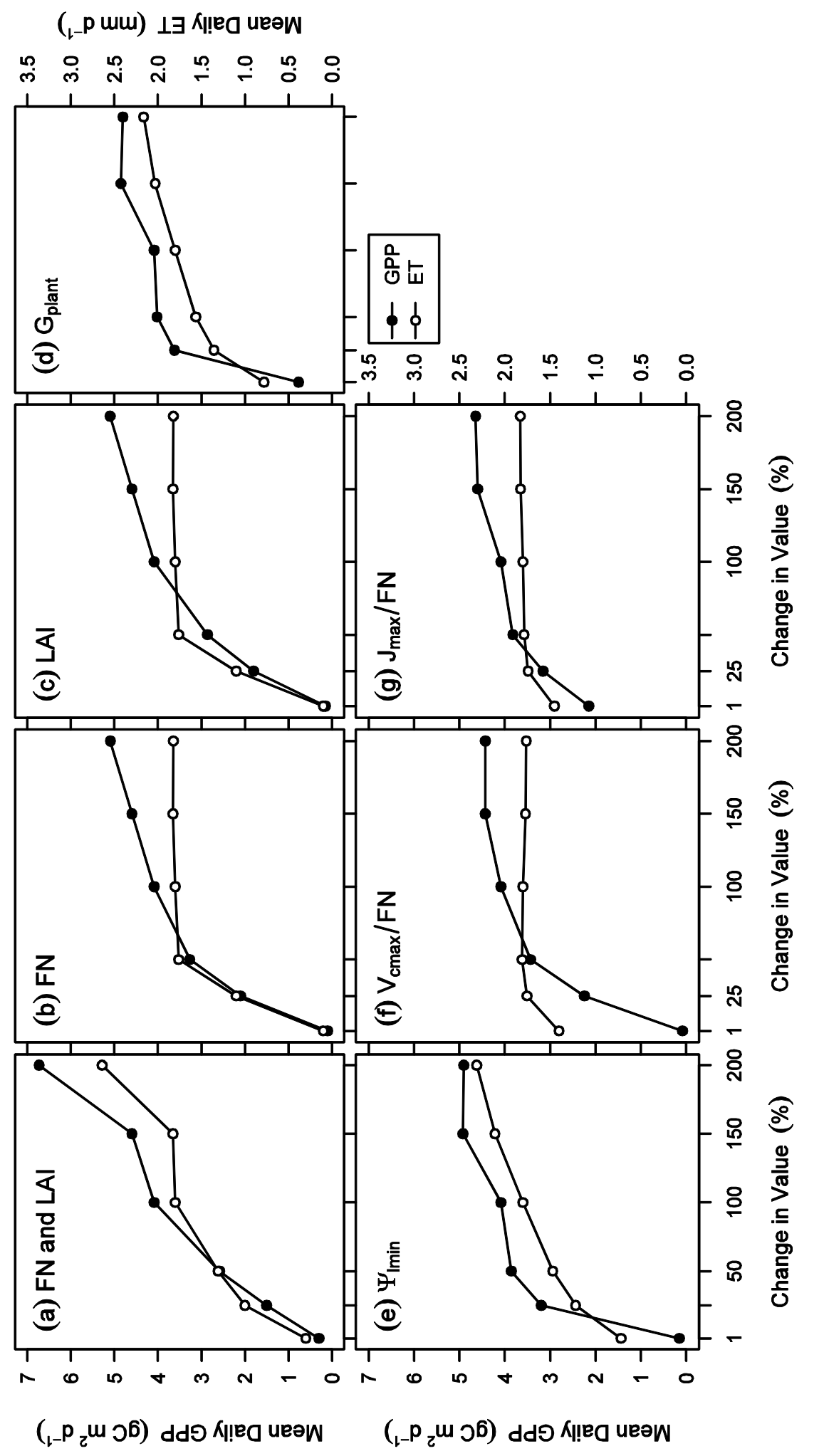




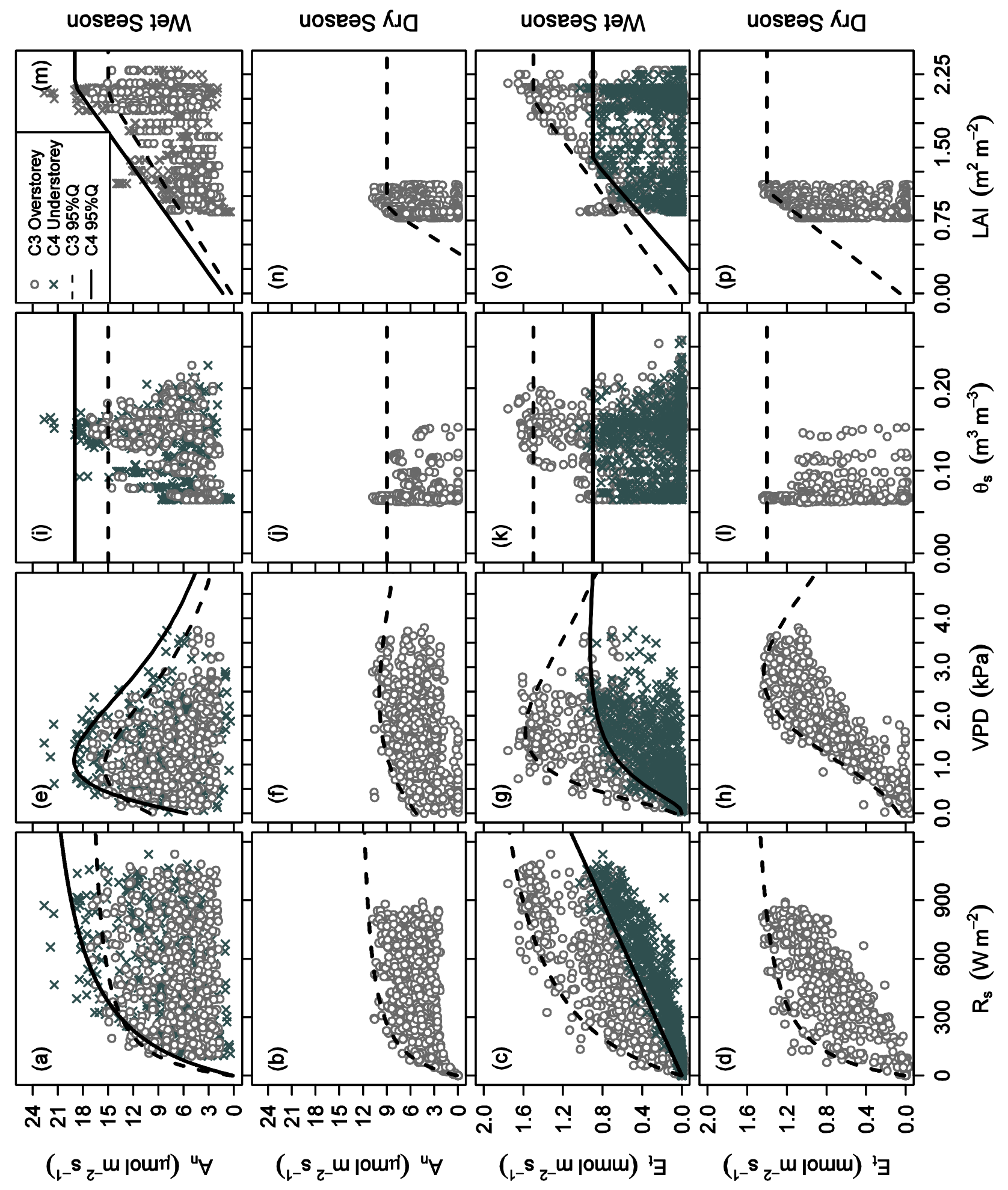

